\title{
Do Tourism and Institutional Quality Asymmetrically Effects on FDI Sustainability in BIMSTEC Countries: An Application of ARDL, CS-ARDL, NARDL, and Asymmetric Causality Test
}

\author{
Yixing Yang ${ }^{1}$, Md. Qamruzzaman ${ }^{2}\left(\mathbb{D}\right.$, Mohd Ziaur Rehman $^{3}$ and Salma Karim ${ }^{2, *(1)}$ \\ 1 Economics and Education, Teachers College, Columbia University, New York, NY 10027, USA; \\ guxuan7303@163.com \\ 2 School of Business and Economics, United International University, Dhaka 1212, Bangladesh; \\ qamruzzaman@bus.uu.ac.bd \\ 3 Department of Finance, College of Business Administration, King Saud University, \\ Riyadh 11587, Saudi Arabia; ziacommerce@gmail.com \\ * Correspondence: ska@bus.uiu.ac.bd
}

check for updates

Citation: Yang, Y.; Qamruzzaman, M.; Rehman, M.Z.; Karim, S. Do Tourism and Institutional Quality Asymmetrically Effects on FDI Sustainability in BIMSTEC Countries: An Application of ARDL, CS-ARDL, NARDL, and Asymmetric Causality Test. Sustainability 2021, 13, 9989. https://doi.org/10.3390/su13179989

Academic Editor: Luigi Aldieri

Received: 3 August 2021

Accepted: 31 August 2021

Published: 6 September 2021

Publisher's Note: MDPI stays neutral with regard to jurisdictional claims in published maps and institutional affiliations.

Copyright: (c) 2021 by the authors. Licensee MDPI, Basel, Switzerland. This article is an open access article distributed under the terms and conditions of the Creative Commons Attribution (CC BY) license (https:/ / creativecommons.org/licenses/by/ $4.0 /)$.

\begin{abstract}
The motivation of the study is to investigate the nature of the relationship between institutional quality, tourism, and FDI in BIMSTEC nations for the period 1996Q1-2018Q4. Exploring their nature of association, the study performed several panel econometric models, namely Panel ARDL, Nonlinear ARDL, and Toda-Yamamoto causality test, with symmetric and asymmetric effects of institutional quality and tourism. The results of the Wald test confirmed the long-run asymmetric relationship between institutional quality, tourism, and FDI, both in the long-run and short-run. Furthermore, directional casualty established a feedback hypothesis explaining the relationship between institutional quality, tourism, and FDI.
\end{abstract}

Keywords: institutional quality; tourism; FDI; ARDL; NARDL; asymmetric-causality

\section{Introduction}

Foreign direct investment (FDI) is important for economic progress, especially for developing nations. Hence, developing nations have been keen to accept foreign investment since FDI bridges capital, technological expertise, and management gap between domestic and foreign firms. Thus, by allowing FDI in the economy, countries can spur their investment possibilities, in the top prioritized area(s), in the economy that eventually expedite the hustle of economic growth in the long run. Furthermore, in globalization, $F D I$ is considered an important stimulator of productivity enhancement, technological advancement, and job creation. The study by Quazi [1] advocated that FDI accelerates economic growth, playing a vital role in tax revenue, foreign exchange, and development gaps in developing and transition economies.

The motivation of the study is to gauge the role of tourism and institutional development on FDI inflows in BIMSTEC Countries. The study implemented both symmetry and asymmetry frameworks of exploring the insight evidence in empirical assessment. The study detected that FDI inflows positively augmented further development in tourism and institutional quality in BIMSTEC countries. BIMSTEC is a sub-regional organization comprised of seven South and Southeast Asian nations. Its mission is to foster economic growth, accelerate social advancement, and foster cooperation on issues of mutual concern in the Bay of Bengal. The underlying motivation for selecting BIMSTEC as a panel is sharing the common economic dynamics and economic integration.

Acknowledging the potential effects of FDI in the economy, a growing number of studies were performed targeting to discover the key determinants of FDI inflows. Empirical literature signifies several macro fundaments including, level of economic development [2,3], financial markets development [4-6], human capital [7-9], quality infrastructure [10], size 
of the market [11,12], the infrastructure of the host country [13], interest rate [14], the exchange rate [15], inflation [16], trade openness and domestic investment [17], good governance [18], and so on.

The novelty of this study lies in the following actualities. First, in the study, the effect on FDI will be investigated by considering the three aspects. As part of the contributions of this study, we employ three dependent variables-flows of FDI (\% of GDP) and stock of $F D I$ and $F D I$ volatility. The volatility of $F D I$ is measured by the variance of $F D I$ following Buchanan et al. [19]. The underlying motivation for selecting three proxies so that broad aspects of the empirical nexus can be investigated and side-by-side unleash conclusive evidence. Second, the long and short-run magnitude of tourism and institutional quality on FDI will be investigated applying both PGM-ARDL and CS-ADRL. Third, to our best knowledge, for the first time, asymmetric effects of institutional quality and tourism on FDI were investigated by following a nonlinear framework imitated by Shin et al. [20]. Finally, the directional relationship between institutional quality, tourism, and FDI is to be assessed by following the non-granger causality framework proposed by Toda and Yamamoto [21] with symmetric and asymmetric effects of institutional quality and tourism in the empirical equation.

Study findings revealed that both institutional quality and tourism positively influence the inflows of $F D I$, especially in the long run. These findings have been confirmed by both panel ARDL and CS-ARDL estimation. Referring to asymmetry assessment, the study findings revealed that the results of the Wald test, both in the long-run and short-run, are statistically significant, implying the presence of an asymmetric relationship between institutional quality, tourism, and FDI in BEMISTEC countries during 1996-2018. Furthermore, the causality test disclosed the feedback hypothesis for explaining the causality between institutional quality, tourism, and FDI symmetry. The asymmetric casualty tests recognized bidirectional casualty running between negative shocks in institutional quality, tourism, and FDI. However, unidirectional causality runs from FDI to positive shocks in institutional quality and tourism, respectively.

The paper is structured as follows. Section 2 deals with the empirical literature survey on the nexus between institutional quality, tourism, and FDI. Data sources, descriptions of variables, and econometric methodologies are explained in Section 3. Empirical models estimation and their interpretation are reported in Section 4. Finally, summary findings and policy implications are displayed in Section 5.

\section{Literature Review}

\subsection{Nexus between Tourism and FDI}

According to existing literature, two lines of evidence are available focusing on the nexus between FDI and Tourism. First, FDI-led tourism development, suggesting that foreign investors assist a nation in increasing tourism by upgrading tourist attractions and transportation and lodging facilities such as airports and hotels [22-24] and tourism-led $F D I$ in the economy $[25,26]$.

International tourism has been one of the world's fastest expanding industries and a significant source of foreign revenue for many nations [27]. Moreover, its effect on a country's economy is often measured in terms of GDP growth. An economy's potential to profit from tourism is contingent upon the availability of (international) money to invest in infrastructure development, particularly transportation and lodging services. In recent years, the tourism industry has risen to become a primary industry, generating an increasingly significant source of foreign money needed to fund development. There are significant impacts on the economy when it comes to tourism growth. While tourism's advantages are not confined to a certain segment of society, the breadth of the population that they reach is greater than those benefits derived from other sectors of the economy [28]. The growth of the tourism industry expedites economic growth, offering employment and sources of income, which eventually increase the standard of living in society. The important role of tourism development in economic prosperity in literature is based on the 
tourism-led growth hypothesis $[29,30]$. Tourism development, especially in developing nations, only accelerates export earning with manufacturing industries and assists the services industry to thrive with employment opportunities. Tourism-related sectors are anticipated to see greater inflows of foreign direct investment (FDI) as a result of an increase in tourism [29]. Thus, under this assumption, tourism-related FDI is considered a key mechanism for economic growth [31].

Referring to tourism-led FDI, empirical studies have produced three-line findings. The first line of research established positive effects running from Tourism to FDI. In this regard, supporting the demand leading hypothesis, that is, tourism augments the inflows of FDI in the host economy, see, for instance, Perić and Radić [32], Katircioglu et al. [33]; Kaur and Sarin [34], Tomohara [31]. On the other hand, the supply leading hypothesis was also established in empirical studies, which suggests that foreign direct investment accelerates tourism development by allowing expansion growth see, for instance, Vorley [35], Ivanovic et al. [36], Siddiqui and Siddiqui [37], Arain et al. [38] and, Arain, Sharif, Akbar, and Younis [38].

The second line of thought supports the "feedback hypothesis", that is, bidirectional causality running between Tourism-FDI see, for instance, Arain, Sharif, Akbar and Younis [38]; Satrovic [39]; Salleh et al. [40], Sokhanvar [24]. Finally, the neutral relationship is also observed in the literature; it implies that tourism does not play any role in augmenting the recipients of FDI in the host economy. See, for instance, Khoshnevis Yazdi and Shakouri [41].

Samimi, Sadeghi, and Sadeghi [29] conducted a study investigating the role of tourism on FDI inflows in Japan data for the 1996-2011 period by utilizing the system GMM estimation. The study findings document the supporting evidence favoring tourism-led $F D I$ in Japan. The study findings postulated that increased incoming international tourism has spillover effects that extend beyond the tourism-related industries to other sectors. Further evidence is available in the study of Chang and Chang [42]. The study suggests that growth in inbound tourism can boost $F D I$ inflows to tourism businesses and FDI inflows to other sectors. The summary of the literature survey is displayed in Table 1. In other words, flourishing inbound tourism may have spillover effects on non-tourism industries.

Table 1. Summary of literature survey.

\begin{tabular}{|c|c|c|c|c|c|}
\hline Author & Time & Country & Methodology & Effects & Causality \\
\hline \multicolumn{6}{|c|}{ Panel-A: Based on Time series } \\
\hline Perić and Radić [32] & 2000 to 2012 & Croatia & VAR, TYC & $\mathrm{VE}+$ & \\
\hline Arain et al. [43] & 1995 to 2017 & $\begin{array}{l}\text { China, Russia, Mexico, } \\
\text { Spain, and Turkey }\end{array}$ & GCT & VE- & $\leftarrow \rightarrow$ \\
\hline Katircioglu [44] & 1970 to 2005 & Turkey & ARDL & VE+ & $\mathrm{T} \rightarrow F D I$ \\
\hline Kaur and Sarin [34] & 1991 to 2014 & India & VAR, GCT & $\mathrm{VE}+$ & $\rightarrow$ \\
\hline Satrovic and Muslija [45] & 1995 to 2015 & Turkey & VAR, GCT & $\mathrm{VE}+$ & $\leftarrow \rightarrow$ \\
\hline Khoshnevis Yazdi et al. [46] & 1985 to 2013 & Iran & $\begin{array}{l}\text { GCT, ARDL, VAR, } \\
\text { VECM }\end{array}$ & $\mathrm{VE}+$ & $\leftarrow \rightarrow$ \\
\hline Sanford, Jr. and Dong [47] & 1988 to 1997 & USA & TOBIT Model & $\mathrm{VE}+$ & \\
\hline$[48]$ & 1995 to 2008 & $\begin{array}{c}\text { India, China, Pakistan, } \\
\text { Russia }\end{array}$ & $\begin{array}{l}\text { Cobb-Douglas } \\
\text { production function }\end{array}$ & VE- & \\
\hline Salleh, Othman and Sarmidi [40] & 1978 to 2008 & $\begin{array}{l}\text { Malaysia, Singapore, } \\
\text { Thailand, China, and } \\
\text { Hong Kong }\end{array}$ & ARDL & $\mathrm{VE}+$ & $\mathrm{T} \leftarrow \rightarrow F D I$ \\
\hline Arain, Han, Sharif, and Meo [43] & 1995 to 2017 & $\begin{array}{l}\text { France, Germany, Italy, } \\
\text { the United Kingdom, } \\
\text { and the United States }\end{array}$ & $\begin{array}{l}\text { QQ method, Granger } \\
\text { causality test }\end{array}$ & VE+ & $\leftarrow \rightarrow$ \\
\hline Muckley [49] & 1970 to 2007 & Northern Ireland & Granger causality tests & VE- & $\leftarrow \rightarrow$ \\
\hline
\end{tabular}


Table 1. Cont.

\begin{tabular}{|c|c|c|c|c|c|}
\hline Author & Time & Country & Methodology & Effects & Causality \\
\hline Vorley [35] & 1990 to 2006 & $\begin{array}{c}\text { Congo, South Sudan, } \\
\text { River Nile, Uganda's } \\
\text { West Nile }\end{array}$ & $\begin{array}{l}\text { Graphical } \\
\text { representation }\end{array}$ & $\mathrm{VE}+$ & \\
\hline Ivanovic, Baresa and Bogdan [36] & 1993 to 2010 & Croatia & Graph & $\mathrm{VE}+$ & \\
\hline Siddiqui and Siddiqui [37] & 1979 to 2017 & Pakistan & $\begin{array}{l}\text { VAR, MARDL, } \\
\text { MVECM }\end{array}$ & VE+ & $\rightarrow$ \\
\hline Arain, Han, Sharif, and Meo [43] & 1995 to 2017 & $\begin{array}{l}\text { France, Germany, Italy, } \\
\text { the United Kingdom, } \\
\text { and the United States }\end{array}$ & $\begin{array}{l}\text { QQ method, Granger } \\
\text { causality test }\end{array}$ & $\mathrm{VE}+$ & $\rightarrow$ \\
\hline Buckley and Geyikdagi [50] & 1980 to 1994 & Turkey & $\begin{array}{l}\text { Theories and } \\
\text { explanation. }\end{array}$ & $\mathrm{VE}+$ & \\
\hline Ma et al. [51] & 1983 to 2017 & China & $\begin{array}{c}\text { Granger causality test, } \\
\text { TVP-VAR }\end{array}$ & VE+ & $\leftarrow \rightarrow$ \\
\hline Selvanathan et al. [52] & 1995 to 2007 & India & VAR & $\mathrm{VE}+$ & $\rightarrow$ \\
\hline Ravinthirakumaran et al. [53] & 1978 to 2015 & Sri Lanka & $\begin{array}{l}\text { VAR, ARDL, Granger } \\
\text { causality test }\end{array}$ & VE+ & $\rightarrow$ \\
\hline Subbarao [54] & 2000 to 2007 & India & $\begin{array}{l}\text { Bar diagram data } \\
\text { representation }\end{array}$ & VE+ & \\
\hline Van Parys and James [55] & 1997 to 2007 & Caribbean & $\begin{array}{l}\text { Theories and } \\
\text { explanation. }\end{array}$ & VE+ & \\
\hline Perić and Radıć [56] & 2000 to 2012 & Croatia & ADF test & $\mathrm{VE}+$ & $\rightarrow$ \\
\hline Bezuidenhout and Grater [57] & 2003 to 2012 & Africa & $\begin{array}{c}\text { Graphical } \\
\text { Representation }\end{array}$ & $\mathrm{VE}+$ & $\leftarrow \rightarrow$ \\
\hline Chen [58] & 2006 to 2008 & China & $\begin{array}{c}\text { Graphical } \\
\text { Representation }\end{array}$ & $\mathrm{VE}+$ & \\
\hline Ivanovic, Baresa and Bogdan [36] & 1993 to 2009 & Croatia & $\begin{array}{l}\text { Bar diagram data } \\
\text { representation }\end{array}$ & VE+ & \\
\hline Sharma et al. [59] & 1990 to 2007 & India & $\begin{array}{l}\text { Data representation } \\
\text { and discussion }\end{array}$ & $\mathrm{VE}+$ & \\
\hline Simatupang and Chik [60] & 2006 to 2012 & $\begin{array}{c}\text { Indonesia Sumatra } \\
\text { utara }\end{array}$ & Regression analysis & VE+ & $\leftarrow \rightarrow$ \\
\hline Willem te Velde and Nair [61] & 1997 to 2003 & Caribbean & OLS estimator & $\mathrm{VE}+$ & \\
\hline DALY et al. [62] & 1980 to 1993 & Australia, Japan & $\begin{array}{l}\text { Graphical } \\
\text { representation }\end{array}$ & $\mathrm{VE}+$ & \\
\hline Satrovic and Muslija [45] & 1995 to 2015 & Turkey & $\begin{array}{l}\text { VAR, Granger } \\
\text { causality test }\end{array}$ & VE+ & $\leftarrow \rightarrow$ \\
\hline \multicolumn{6}{|c|}{ Category B: Based on Panel data } \\
\hline Fereidouni and Al-mulali [25] & 1995 to 2009 & OECD Countries & $\begin{array}{c}\text { ADF test, Granger } \\
\text { cointegration test, } \\
\text { Granger causality test }\end{array}$ & $\mathrm{VE}+$ & $\leftarrow \rightarrow$ \\
\hline Barrowclough [63] & 2006 & $\begin{array}{l}39 \text { Small Island } \\
\text { Developing States }\end{array}$ & $\begin{array}{l}\text { Bar diagram } \\
\text { representation }\end{array}$ & $\mathrm{VE}+$ & \\
\hline Tomohara [31] & 1996 to 2011 & Japan & ARDL, GMM & $\mathrm{VE}+$ & $\rightarrow$ \\
\hline Samimi, Sadeghi and Sadeghi [29] & 1995 to 2008 & Developing Countries & VECM, PP, ADF & $\mathrm{VE}+$ & $\leftarrow \rightarrow$ \\
\hline Peric and Niksic Radic [64] & 1995 to 2010 & Developing Countries & $\begin{array}{c}\text { Graphical } \\
\text { Representation }\end{array}$ & VE+ & \\
\hline Işik [65] & 1980 to 2012 & D7 Countries & $\mathrm{ADF}$ & $\mathrm{VE}+$ & $\rightarrow$ \\
\hline Fortanier and Van Wijk [66] & $\begin{array}{l}123 \text { hotel sample } \\
\text { from } 2006\end{array}$ & $\begin{array}{c}\text { Sub-Saharan African } \\
\text { countries }\end{array}$ & Regression analysis & VE+ & \\
\hline
\end{tabular}


Table 1. Cont.

\begin{tabular}{|c|c|c|c|c|c|}
\hline Author & Time & Country & Methodology & Effects & Causality \\
\hline Khoshnevis Yazdi et al. [67] & 1995 to 2014 & EU countries & ARDL, VAR, ECM & VE+ & \\
\hline Fayissa et al. [68] & 1990 to 2005 & $\begin{array}{l}\text { Latin American } \\
\text { countries }\end{array}$ & GMM & $\mathrm{VE}+$ & $\leftarrow \rightarrow$ \\
\hline Sokhanvar [24] & 1971 to 2010 & Europe & VAR, ARDL & VE- & $\leftarrow \rightarrow$ \\
\hline Phung-Tran and Trang-Le [69] & 1980 to 2012 & $\begin{array}{l}\text { Italy, Spain, Germany, } \\
\text { Turkey, and the United } \\
\text { Kingdom }\end{array}$ & $\begin{array}{l}\text { Granger causality } \\
\text { analysis }\end{array}$ & $\mathrm{n} / \mathrm{a}$ & $\rightarrow$ \\
\hline Tomohara [31] & 1996 to 2011 & Japan & GMM & VE+ & \\
\hline \multicolumn{6}{|c|}{ Category C: Papers based on Bangladesh } \\
\hline Das and Chakraborty [70] & 2004 to 2010 & Bangladesh & $\begin{array}{l}\text { GDP Growth } \\
\text { Representation }\end{array}$ & VE+ & \\
\hline Hassan et al. [71] & 1991 to 2010 & Bangladesh & $\begin{array}{l}\text { Graphical analysis of } \\
\text { GDP }\end{array}$ & $\mathrm{VE}+$ & \\
\hline Aktar et al. [72] & 2004 to 2010 & Bangladesh & VAR & $\mathrm{VE}+$ & \\
\hline Chowdhury and Shahriar [73] & Fully conceptual & Bangladesh & Conceptual & $\mathrm{VE}+$ & $\rightarrow$ \\
\hline
\end{tabular}

Sources: authors' accumulation. Note. $\leftarrow \rightarrow$ for bidirectional causality and $\leftarrow / \rightarrow$ of unitdirectional causality.

\subsection{Institutional Quality and FDI Nexus}

In recent research, the institutional quality of a host nation has gained increasing attention as one of the major factors in foreign capital investment decisions. Institutional factors such as legal and political systems are considered critical in reducing the risk of opportunism in foreign direct investment $(F D I)$. Furthermore, less corruption and a fair, reliable, and efficient bureaucracy assist in attracting foreign direct investment. Nexus between institutional quality and FDI has been investigated extensively in the empirical literature, and a growing number of researchers have confirmed positive associations, including Bouchoucha and Benammou [74]; Masron and Abdullah [75]; Masron and Naseem [76]; Shah et al. [77]. Quality institutions, according to Hall and Jones [78], accelerate the growth phenomena by encouraging private investments and improving the overall efficiency of the economic system. The theoretical literature supports the importance of efficient and wellperforming institutions in disciplining economic actors' conduct and enacting rules and regulations that restrict opportunism and foster transactional trust in financial transactions, thus increasing foreign investor confidence and FDI inflows. In a study by Globerman and Shapiro [79], they contended that stronger institutions may benefit FDI inflows by creating favorable conditions for foreign investors. Additionally, they discovered that various metrics of governance quality had a somewhat varied effect on FDI inflows. The study of Masron [80] advocated that although raising IQ is a good thing, it does not always translate into greater FDI. That is, IQ is a required but not sufficient condition for FDI inflows. Ongoing efforts to strengthen ASEAN economies should improve labor markets, natural resource supply stability, and physical infrastructure.

Possessing quality institutions in the economy, countries can have experienced additional benefits for receiving $F D I$ in various ways. First, quality institutions and productivity are interlinked in the long run, and the possibility of achieving higher productivity encourages foreign investors to invest in the economy. Second, an unfavorable institutional environment may raise the cost of conducting business. Corruption, for example, may discourage investment by raising the cost of conducting business. Third, since FDI entails a large sunk cost, it is susceptible to uncertainty, particularly caused by poor government efficiency. Improper contract enforcement, for example, may raise uncertainty about future returns and, as a result, have a detrimental impact on investment.

Regarding IQ and FDI nexus, another group of researchers has observed the adverse association [19,81-83]. In the study of North [84], the study findings postulated that ineffi- 
cient institutions are responsible for increasing the production costs through disrupting the supply chain, and excessive formalities in obtaining permits can significantly increase production costs.

However, the empirical literature has also exposed neutral effects running between IQ and FDI, see [85-87]. Furthermore, the indirect effects of institutional quality on FDI inwards are also investigated and established in empirical studies such as human capital, healthy labor force, and the quality of public facilities to promote FDI [88]. The study of Michael Michael et al. [89] investigated the moderating effects of institutional quality on inflows of FDI in 40 countries in the Sub-Saharan African region over the period from 1996 to 2011. The study findings revealed that institutional quality augmented the inflows of FDI by reducing the negative effects of macroeconomic uncertainty. The summary of survey literature is displayed display in Table 2.

Table 2. Summary of literature survey.

\begin{tabular}{|c|c|c|c|c|}
\hline Authors & Location & Time & Methodology & Causality \\
\hline \multicolumn{5}{|c|}{ Category A: Based on Time series } \\
\hline Haile and Assefa [90] & Ethiopia & $1974-2004$ & ADF test & \\
\hline Ramirez [91] & Not specified & 1960-2001 & VECM & \\
\hline Nasrin et al. [92] & Bangladesh & 1998-2007 & GR & \\
\hline Esew and Yaroson [93] & Nigeria & 1980-2011 & VECM & $\rightarrow$ \\
\hline Fadhil and Almsafir [94] & Malaysia & 1975-2010 & $\mathrm{ADF}$ & $\rightarrow$ \\
\hline Shah, Ahmad, and Ahmed [77] & Pakistan & 1980-2012 & ARDL & $\leftarrow \rightarrow$ \\
\hline Nguyen and Cao [95] & Vietnam & $1996-2011$ & H-Test & \\
\hline Hussain and Haque [96] & Bangladesh & 1973-2014 & VECM analysis & $\rightarrow$ \\
\hline Mahmood [97] & Bangladesh & $1975-2015$ & $\mathrm{ADF}$ & $\leftarrow \rightarrow$ \\
\hline \multicolumn{5}{|c|}{ Category B: Based on Panel data } \\
\hline Chowdhury and Mavrotas [98] & 2 countries & $1969-2000$ & ADF test & $\leftarrow \rightarrow$ \\
\hline Busse and Hefeker [99] & 83 developing & $1984-2003$ & GMM & \\
\hline Hyun [100] & 62 developing & $1984-2003$ & System GMM & $\leftarrow \rightarrow$ \\
\hline Mina [101] & 6 GCC countries & 1980-2002 & OLS & \\
\hline Kostevc et al. [102] & 24 transition economies & 1995-2002 & RA & \\
\hline Bénassy-Quéré et al. [103] & 37 OECD countries & 1985-2000 & RA & \\
\hline Daude and Stein [104] & 34 countries & $1982-2002$ & OLS & \\
\hline Rose-Ackerman and Tobin [105] & 63 countries & $1991-2000$ & RA & \\
\hline Hattari and Rajan [106] & 24 countries & 1990-2005 & RA & \\
\hline Ali et al. [107] & 69 countries & 1981-2005 & RA & \\
\hline Shahadan et al. [108] & 6 Asian countries & $2004-2013$ & OLS method & \\
\hline Masron and Abdullah [75] & 8 ASEAN & $1996-2008$ & OLS & \\
\hline Fukumi and Nishijima [109] & 19 countries & $1983-2000$ & OLS & \\
\hline Bissoon [110] & 45 developing & 1996-2005 & OLS & \\
\hline Buchanan Le and Rishi [19] & 164 countries & 1996-2006 & OLS & $\rightarrow$ \\
\hline Tun et al. [111] & 77 countries & $1981-2005$ & System GMM & \\
\hline Asiedu [112] & 99 developing & $1984-2011$ & System GMM & $\rightarrow$ \\
\hline Dang [113] & 60 provinces of Vietnam & $2006-2007$ & OLS, GMM & \\
\hline Fiodendji [114] & 30 African countries & 1984-2007 & ADF & \\
\hline Cristina and Levieuge [115] & 94 developing & $1984-2009$ & PSTR & \\
\hline Masron and Nor [116] & 10 ASEAN countries & $2002-2010$ & $\mathrm{ADF}$ & \\
\hline Herrera-Echeverri et al. [117] & 87 countries & $2004-2009$ & RA & \\
\hline Jude and Levieuge [118] & 94 developing countries & $1984-2009$ & PSTR Model & \\
\hline Asamoah et al. [119] & 40 countries & 1996-2011 & ADF Test & \\
\hline Kurul and Yalta [120] & 113 developing & $2002-2012$ & OLS method & \\
\hline Kurul [121] & 126 countries & $2002-2012$ & System GMM & \\
\hline Jude and Levieuge [122] & 93 developing & $1984-2009$ & System GMM & $\rightarrow$ \\
\hline Bokpin et al. [123] & 49 African countries & 1980-2011 & System GMM & \\
\hline Aziz [124] & 16 Arab countries & $1984-2012$ & System GMM & \\
\hline Van Bon [125] & 43 countries & $2005-2012$ & System GMM & $\rightarrow$ \\
\hline Asiedu [112] & 99 developing & 1984-2011 & System GMM & $\rightarrow$ \\
\hline
\end{tabular}




\subsection{The Motivation of the Study and Proposed Hypothesis of the Study}

Concerning the literature survey, it is apparent that many empirical studies have already been conducted by taking account of several macroeconomic fundamentals with time series and panel data. However, the nexus between institutional quality, tourism, and FDI is yet to be investigated, and their possible asymmetry is still undiscovered in the empirical literature.

Furthermore, it is obvious that directional causality is investigated extensively; however, their asymmetric causality relationship is yet to be unleashed. Therefore, with this study, for the first time, the possible asymmetric relationship between Tourism and FDI will be investigated by applying the nonlinear framework propose by Shin, Yu, and Greenwood-Nimmo [20] in panel form, and asymmetric directional causality will be assessed by following Toda and Yamamoto [21] causality test with the asymmetry of tourism in the equation. It is expected that the current research findings will contribute towards fulfilling the existing research gap and put another view for explaining the nexus between institutional quality, tourism, and FDI that is asymmetry effects. Figure 1 displays the conceptual and hypnotized empirical model for hypothesis testing.

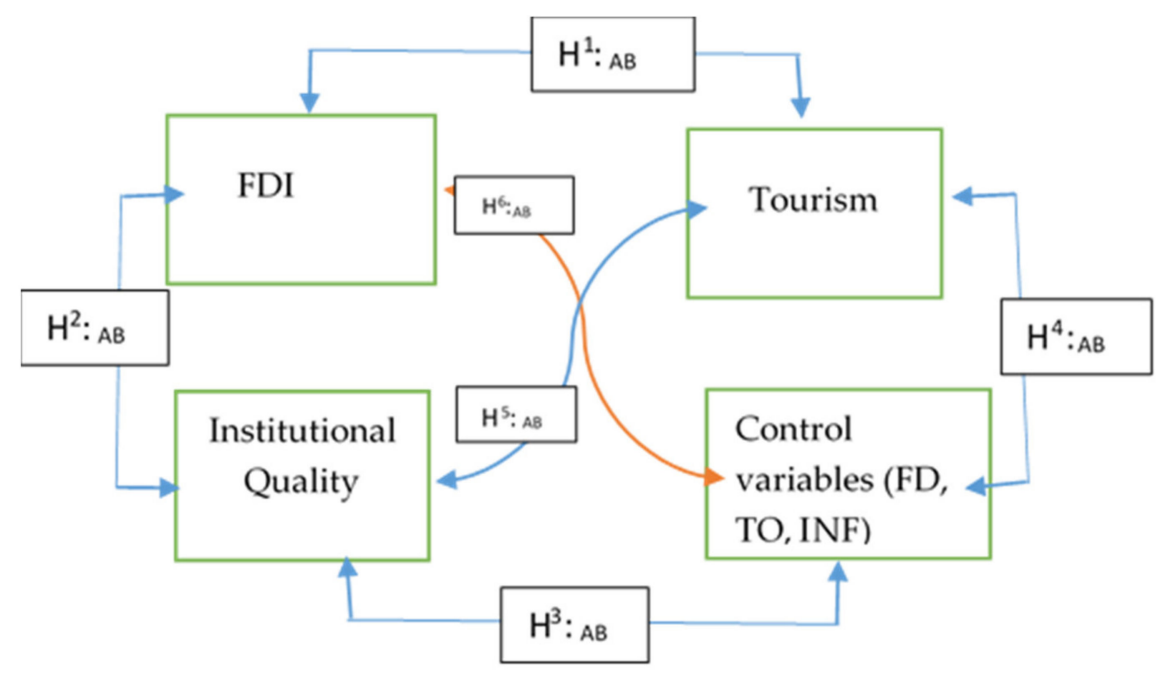

Figure 1. Conceptual and Hypnotized model for hypothesis testing. $\mathrm{H}^{1}:{ }_{\mathrm{AB}}$ : FDI granger causes Tourism and vice versa; $\mathrm{H}^{2}:{ }_{\mathrm{AB}}$ : FDI granger causes Institutional Quality and vice versa; $\mathrm{H}^{3}:{ }_{\mathrm{AB}}$ : Institutional Quality granger causes $C$ and vice versa; $\mathrm{H}^{4}$ : $\mathrm{AB}_{\mathrm{B}}$ : Tourism granger causes Control variables and vice versa; $\mathrm{H}^{5}:{ }_{A B}$ : Institutional quality granger causes Tourism and vice versa; $\mathrm{H}^{6}:{ }_{A B}$ : FDI granger causes Control variables and vice versa.

\section{Data and Methodology of the Study}

To investigate the dynamic relationships between institutional quality, tourism, and FDI, this study considers annual panel data from 1996Q1 to 2018Q4. Except for the proxy variables of institutional quality, all the relevant data were collected from the World $D$ evelopment Indicator published by World Bank. Furthermore, the proxy variables of tourism were collected from Worldwide Governance Indicators (WGI). All the research variables were transformed into a natural log before estimation.

As a dependent variable of the study, the study employed three different proxies, that is, flows of FDI, (\% of GDP) and stock of FDI. The volatility of FDI is measured by the variance of $F D I$ following [19]. The motivation for selecting three proxies is to explore comprehensive and conclusive evidence so that the study findings can contribute substantially to future literature development on the purported topic.

\subsection{Tourism}

Gauging tourism effects on FDI, in the empirical estimation, it is observed that two measures were used extensively. First, international tourism receipts in current 
USD $[46,126,127]$. Second, International tourist arrival is measured by the number of tourism visitors/million People, see for instance $[29,69,128]$. However, a growing number of researchers emphasized using international tourism receipts as a proxy for tourism in the empirical estimation, and this study is on the same trajectory.

\subsection{Institutional Quality}

Measuring institutional quality in the empirical literature, two lines of thought are available. A growing number of empirical studies have utilized a single proxy for IQ in these respective studies see, for instance, Aizenman and Spiegel [129]; Levchenko [130]; Habib and Zurawicki [131]; Wijeweera and Dollery [132]. The second line of empirical findings have been suggesting the use of index measures for institutional quality, which is constructed by taking into account the indicators from World Governance Indicators [133] with the application of Principal component analysis see for an instance Le et al. [134]; Qamruzzaman, Tayachi, Mehta, and Ali [18]; Daude and Stein [104]. In regards to institutional quality measurement, the present study follows the second line of under sting that is the use of the institutional quality index following Qamruzzaman, Tayachi, Mehta, and Ali [18]; Asamoah, Adjasi, and Alhassan [119]; Buchanan, Le, and Rishi [19]. The pair-wise correlation of six indicators of WGI is displayed in Table 3 and the output of PCA is reported in Table 4.

Table 3. Pair-wise correlation of Institutional quality proxies (WGI).

\begin{tabular}{ccccccc}
\hline & $\mathbf{v}$ & ps & GE & RQ & L & CC \\
\hline v & 1 & & & & & \\
ps & 0.725652 & 1 & & & & \\
GE & 0.518462 & 0.582931 & 1 & & & \\
RQ & 0.678391 & 0.640665 & 0.73532 & 1 & & \\
L & 0.709744 & 0.509499 & 0.879439 & 0.799107 & 1 & 1 \\
CC & 0.338795 & 0.725775 & 0.837552 & 0.492579 & 0.792911 & 1 \\
\hline
\end{tabular}

Source: Authors' estimation.

Table 4. Principle component analysis.

\begin{tabular}{|c|c|c|c|c|c|}
\hline \multicolumn{6}{|c|}{ Eigenvalues: $($ Sum $=6$, Average $=1)$} \\
\hline & & & & Cumulative & Cumulative \\
\hline Number & Value & Difference & Proportion & Value & Proportion \\
\hline $\mathrm{V}$ & 2.252428 & 1.188895 & 0.3754 & 2.252428 & 0.3754 \\
\hline ps & 1.063533 & 0.067749 & 0.1773 & 3.315961 & 0.5527 \\
\hline GE & 0.995784 & 0.213037 & 0.1660 & 4.311745 & 0.7186 \\
\hline $\mathrm{RQ}$ & 0.782747 & 0.177102 & 0.1305 & 5.094493 & 0.8491 \\
\hline $\mathrm{L}$ & 0.605645 & 0.305782 & 0.1009 & 5.700137 & 0.9500 \\
\hline $\mathrm{CC}$ & 0.299863 & - & 0.0500 & 6.000000 & 1.0000 \\
\hline \multicolumn{6}{|c|}{ Eigenvectors (loadings): } \\
\hline Variable & PC 1 & PC 2 & PC 3 & PC 4 & PC 5 \\
\hline $\mathrm{V}$ & 0.268545 & 0.557438 & -0.360042 & 0.689054 & -0.091162 \\
\hline ps & 0.568638 & -0.120562 & 0.254088 & -0.086339 & -0.172971 \\
\hline GE & 0.515108 & -0.076211 & -0.212609 & -0.280558 & -0.594712 \\
\hline $\mathrm{RQ}$ & 0.392958 & -0.301011 & 0.536961 & 0.451578 & 0.314848 \\
\hline $\mathrm{L}^{2}$ & 0.146198 & 0.755777 & 0.439561 & -0.400875 & 0.182049 \\
\hline $\mathrm{CC}$ & 0.404239 & -0.084337 & -0.528267 & -0.272791 & 0.689795 \\
\hline
\end{tabular}

Source: Authors' estimation.

As a result, following existing literature, see, for instance, Asamoah and Alagidede [135], Globerman and Shapiro [88], the study performed principal components of the six indicators of governance employing factor analysis and construct instructional quality index (IQ). The results of PCI are exhibited in Table 4. 
Apart from the target variables, following existing literature see Carkovic and Levine [136] and Hayat [137], the study considers a list of control variables for robustness in empirical estimation such as trade openness (TO) measured by the sum of export and import as a percentage of GDP. Domestic investment (DI) is measured by gross capital formation as a percentage of GDP, inflation (INF) is measured by consumer price index and money supply (M) which is proxied by Broad money as a percentage of GDP.

Considering all proxies representing FDI in the empirical equation, the generalized empirical model in panel form can be represented in the following Equations (1)-(3), and different methodologies will be applied for assessment purposes.

$$
\begin{gathered}
F D I_{i t}=\alpha_{t}+\beta \text { Inst }_{i t}+\gamma \operatorname{Tour}_{i, t}+\mu X_{i t} \partial_{i, t}+\varphi_{i t} \\
F D I \_ \text {stock }_{i t}=\alpha_{t}+\beta \text { Inst }_{i t}+\gamma \operatorname{Tour}_{i, t}+\mu X_{i t} \partial_{i, t}+\varphi_{i t} \\
\text { FDI_volatility }{ }_{i t}=\alpha_{t}+\beta \text { Inst }_{i t}+\gamma \operatorname{Tour}_{i, t}+\mu X_{i t} \partial_{i, t}+\varphi_{i t}
\end{gathered}
$$

The subscripts $i$ and $t$ denote the sample countries $(i=1,2, \ldots, N)$ and months $(t=1,2, \ldots, T)$, respectively. FDI, FDI_stock, and FDI_volatility. FDI are inflows of $F D I$ as $\%$ of GDP, FDI stock as a \% of GDP and FDI volatility is measured by five years standard deviation. Inst indicates a composite index of institutional quality, and Tour represents international tourism receipts. $X_{i t}$ for a group of control variables in the equation, which includes trade openness (TO), money supply (M), domestic investment (DI), and inflation (INF), respectively. The results of the descriptive statistics are exhibited in Table 5.

Table 5. Descriptive statistics.

\begin{tabular}{cccccccccc}
\hline & FI & FS & FV & IQ & TOR & DI & M & TO & INF \\
\hline Mean & 1.629 & 2.149 & 0.602 & -0.528 & 3.006 & 3.431 & 4.054 & 3.956 & 1.607 \\
Median & 1.188 & 2.36 & 0.317 & -0.519 & 2.987 & 3.358 & 4.059 & 3.919 & 1.757 \\
Maximum & 6.842 & 4.129 & 3.381 & 0.443 & 3.199 & 4.238 & 4.844 & 4.939 & 2.768 \\
Minimum & -0.191 & -0.357 & 0.032 & -1.943 & 2.747 & 2.937 & 2.965 & -1.787 & -1.67 \\
Std. Dev. & 1.471 & 1.128 & 0.698 & 0.574 & 0.107 & 0.281 & 0.412 & 0.865 & 0.703 \\
Skewness & 1.431 & -0.211 & 2.071 & -0.82 & 0.106 & 0.892 & -0.044 & -4.296 & -1.724 \\
Kurtosis & 4.889 & 2.151 & 7.213 & 3.417 & 2.049 & 3.228 & 2.557 & 29.249 & 7.718 \\
Jarque-Bera & 62.795 & 4.796 & 186.209 & 15.275 & 5.056 & 17.258 & 1.086 & 4068.603 & 182.147 \\
\hline
\end{tabular}

Source: Authors' estimation.

\subsection{Estimation Strategies}

\subsubsection{Cross-Sectional Dependency Test}

The cross-section dependence test is critical in panel data empirical research, particularly when representative nations have similar economic features, such as emerging countries, growing economies, and transition countries. A similar economy is vulnerable to the impacts of any shock in other countries due to trade internationalization, financial integration, and globalization. As a consequence, cross-sectional dependency analysis is often needed in empirical research using panel data. According to existing literature, a number of CSD tests have emerged and been applied for detecting the presence of common dynamics in research units, such as $\mathrm{LM}_{\mathrm{BP}}$ test was offered by Breusch and Pagan [138], and the test statistics can be derived with the following equation:

$$
\begin{gathered}
y_{i t}=\alpha_{i}+\beta_{i} x_{i t}+u_{i t} \\
i=1 \ldots . . N, t=1 \ldots . T
\end{gathered}
$$

where $y_{i t}, x_{i t}$ stands for dependent and independent variables and the subscript of $t$, and $i$ represent cross-section and period, respectively. Under the circumstance of larger crosssection units in the model, the $\mathrm{LM}_{\mathrm{BP}}$ test cannot handle the issue. Overcoming the present 
limitation Pesaran [139] proposed the following modified Lagrange multiplier $\left(C D_{l m}\right)$ for examining cross-sectional dependency among research units:

$$
C D_{l m}=\sqrt{\frac{N}{N(N-1)}} \sum_{I=1}^{N-1} \sum_{J=i+1}^{N}\left(T \hat{\rho}_{i j}-1\right)
$$

The empirical model with larger $N$ relative to $T, C D_{l m}$ estimation incapacity to manage this issue and resolve the limitation in $C F_{l m}$, Pesaran [140] offered the following $C D$ test for the situation with larger $N$ than $T$.

$$
C D_{l m}=\sqrt{\frac{2 T}{N(N-1)}} \sum_{I=1}^{N-1} \sum_{J=i+1}^{N}\left(\hat{\rho}_{i j}\right)
$$

Finally, Pesaran et al. [141] familiarized the improved version of $C D_{l m}$ test known as the bias-adjusted LM test, and the test statistics can be derived using the following equation:

$$
C D_{l m}=\sqrt{\frac{2}{N(N-1)}} \sum_{I=1}^{N-1} \sum_{J=i+1}^{N}\left(\frac{(T-K) \hat{\rho}_{i j}^{2}-u_{T i j}}{v_{T i j}^{2}}\right) \vec{d}(N, 0)
$$

where $K$ refers to the number of regresses, $u_{T i j}$ and $v_{T i j}^{2}$ specifies the mean and variance of $(T-K) \hat{\rho}_{i j}^{2}$, respectively.

\subsubsection{Panel Unit Root Tests}

The study performed several unit root tests to discover the properties of the variable, especially with cross-sectional dependency. Second generation panel unit root tests introduced by Pesaran [142], commonly known as CADF and CIPS and have been extensively utilized see [143-145]. The Dickey-Fuller Sectional Augmented Statistics (CADF) can be expressed as:

$$
\Delta X_{i t}=\mu_{i}+\theta_{i} X_{i, t-1}+\gamma_{i} \bar{X}_{t-1}+\sum_{k=1}^{p} \gamma_{i k} \Delta X_{i, k-1}+\sum_{k=0}^{p} \gamma_{i k} \overline{\Delta X}_{i, k-0}+\tau_{i t}
$$

where $Y_{i t}-1$ and $\bar{y}_{t-1}$ stands lagged level average and first difference operator for each cross-section, the CIPS unit root test displays in Equation (9).

$$
\text { CIPS }=N^{-1} \sum_{i-1}^{N} \partial_{i}(N, T)
$$

where the parameter $\partial_{i}(N, T)$ explain the test statistics of $C A D F$, which can be replaced in the following manner:

$$
C I P S=N^{-1} \sum_{i-1}^{N} C A D F
$$

\subsubsection{Panel Cointegration Test}

The present research used several panel cointegration tests following Pedroni Pedroni [146,147], Kao [148] and the bootstrap panel cointegration method developed by Westerlund [149] to find the evidence of a long-run relationship between variables. The Bootstrap panel cointegration technique is more advantageous if each cross section is composed of condensed time series. Because traditional methods do not take CD into account, they accept the null hypothesis of no cointegration even in the presence of CD. 


\subsection{Pooled Grouped Mean Estimation}

For detecting the impact of tourism and institutional quality on FDI inflows, the study considered Panel ARDL familiarized by Pesaran et al. [150], which is capable of identifying both long-run and short-run coefficients in empirical assessment. The first fundamental assumption of PGM is that the error correction term is free from correlation dependency and is normally distributed by regressors. Additionally, the dependent and explanatory variables are related throughout time, which means there will be a long-term correlation between them; finally, the long-term parameters will stay consistent across nations. Pesaran proposed the following ARDL $(p, q \ldots n)$ as an empirical structure:

$$
F D I_{i t}=\epsilon_{i t}+\sum_{j=1}^{p} \beta_{i j} F D I_{i, t-j}+\sum_{j=0}^{q} \gamma_{i j} X_{i, t-j}+\epsilon_{i t}
$$

where,

$$
\begin{gathered}
\epsilon_{i t}=\omega_{t}^{\prime} G_{t}+\varepsilon_{i t} \\
X_{i, t-j}=\alpha_{i}+\beta_{i j} F D I_{i, t-j}+\omega_{t}^{\prime} G_{t}+\mu_{i t}
\end{gathered}
$$

Following Pesaran, Shin, and Smith [150], the following empirical model is used to detect the association between FDI, tourism, and institutional quality in panel assessment.

$$
\Delta F D I_{i t}=\alpha_{i}+\xi_{i}\left(F D I_{i t-1}-\omega_{t}^{\prime} X_{i t-1}\right)+\sum_{J=1}^{M-1} \gamma_{i j} \Delta F D I_{i t-J}+\sum_{J=0}^{N-1} \beta_{i j} \Delta X_{i t-J}+\mu_{i t}
$$

where

$\xi_{i}=-1\left(1-\sum_{j-1}^{M} \gamma_{i J}\right), \omega_{t}^{\prime}=\xi_{i}^{-1} \sum_{j=0}^{N} \beta_{i j}, \gamma_{i, j}^{*}=-\sum_{I=J+1}^{M} \gamma_{i l}$ for $J=1,2, . . M-l$, and $\beta_{i, j}^{*}=-\sum_{I=J+1}^{N} \beta_{i l}$ for $J=1,2, . . N-l .\left(F D I_{i t-1}-\omega_{t}^{\prime} X_{i t-1}\right)$.

Specify the long-run relationship between foreign direct investment and explanatory variables such as institutional quality, tourism, and a list of control variables. The longrun coefficient denoted by $\bar{\omega} i$; and the speed to the recovery of short-run disequilibrium is explained by the vector of $\xi i$ the remaining coefficient (i.e., $\gamma_{i, j^{\prime}}^{*}, \beta_{i j}$ ) in Equation (14) represent the short-run dynamics.

\subsection{Cross-Sectional ARDL}

The presence of cross-sectional dependency among research units has raised inconsistency with traditional panel regression estimation. Thus Chudik and Pesaran [151] proposed an advanced, econometrics technique known as the Common Correlated Effects (CCE) approach for gauging the relationship with panel data, which is the extension of Pesaran [140]. Following the proposed framework, the generalized empirical model is as follows:

$$
\overline{F D I}_{i t}=\bar{\alpha}_{i t}+\sum_{j=1}^{p} \bar{\beta}_{i j} \overline{F D I}_{i, t-j}+\sum_{j=0}^{q} \bar{\gamma}_{i j} \bar{X}_{i, t-j}+\bar{\omega}_{t}^{\prime} G_{t}+\bar{\epsilon}_{i t}
$$

where, $\bar{\alpha}_{i t}=\frac{\sum_{i-1}^{N} \alpha_{i}}{N}$

$$
\begin{gathered}
\overline{F D I}_{t-j}=\frac{\sum_{i}^{N} F D I_{i, t-j}}{N}, \bar{\beta}_{j}=\frac{\sum_{i}^{N} \beta_{i, j}}{N} \quad j=0,1,2 p \\
\bar{X}_{t-j}=\frac{\sum_{i}^{N} X_{i, t} t-j}{N}, \bar{\Upsilon}_{j}=\frac{\sum_{i}^{N} \Upsilon_{i, j}}{N}, J=0,1,2 q \\
\overline{\bar{\omega}}_{j}=\frac{\sum_{i=1}^{N} \omega_{i}}{N}, \bar{\varepsilon}_{t}=\frac{\sum_{i}^{N} \epsilon_{i, t}}{N}
\end{gathered}
$$




$$
\begin{gathered}
F D I_{i t}=\bar{\alpha}_{i t}+\sum_{j=1}^{p} \bar{\beta}_{i j} \overline{F D I}_{i, t-j}+\sum_{j=0}^{q} \bar{\gamma}_{i j} \bar{X}_{i, t-j}+\bar{\omega}_{t}^{\prime} G_{t} \\
\downarrow \\
\bar{\omega}_{t}^{\prime} G_{t}=\overline{F D I}_{i t}-\bar{\alpha}_{i t}+\sum_{j=1}^{p} \bar{\beta}_{i j} \overline{F D I}_{i, t-j}+\sum_{j=0}^{q} \bar{\gamma}_{i j} \bar{X}_{i, t-j} \\
\quad \downarrow \\
G_{t}=\overline{F D I}_{i t}-\bar{\alpha}_{i t}+\sum_{j=1}^{p} \bar{\beta}_{i j} \overline{F D I}_{i, t-j}+\sum_{j=0}^{q} \bar{\gamma}_{i j} \bar{X}_{i, t-j} / \bar{\omega}_{t}^{\prime}
\end{gathered}
$$

Thus, the Panel CS-ARDL specification of Equation (15)

$$
\overline{F D I}_{i t}=\epsilon_{i t}+\sum_{j=1}^{p} \beta_{i j} \overline{F D I}_{i, t-j}+\sum_{j=0}^{q} \gamma_{i j} \bar{X}_{i, t-j}+\sum_{j=0}^{p} \bar{\partial}_{t j}^{\prime} \bar{Z}_{i, t-j}+\epsilon_{i t}
$$

where, $\bar{Z}=(\overline{F D I}, \bar{X})$ and $S_{\bar{Z}}$ in the number of lagged cross-sectional average, Similarly Equation (11) can be reparametrized to the effects of ECM presentation of Panel CS-ARDL as follows:

$$
\begin{aligned}
\Delta F D I_{i t}=\alpha_{i}+ & \xi_{i}\left(F D I_{i t-1}-\omega_{t}^{\prime} X_{i t-1}\right)+\sum_{J=1}^{M-1} \gamma_{i j} \Delta F D I_{i t-J}+\sum_{J=0}^{N-1} \beta_{i j} \Delta X_{i t-J}+\sum_{j=1}^{p} \lambda_{j} \overline{\Delta F D I}_{i, t-j} \\
+ & \sum_{j=0}^{q} \delta_{j} \overline{\Delta X}_{i, t-j}+\sum_{j=0}^{S_{\bar{Z}}} \bar{\partial}_{t j}^{\prime} \bar{Z}_{i, t-j}+\mu_{i t} \\
& \text { where }{\overline{\Delta F D I_{t-j}}}_{t}=\frac{\sum_{i}^{N} \Delta F D I_{i, t-j}}{N}, \overline{\Delta X}_{t-j}=\frac{\sum_{i}^{N} \Delta X_{i, t-j}}{N} .
\end{aligned}
$$

\subsection{The Asymmetric Panel ARDL}

The study implements a nonlinear framework following Shin, Yu, and GreenwoodNimmo [20] in panel form to evaluate the asymmetric effects of tourism and institutional quality on FDI inflows. Taking into account the positive and negative shocks that are (TOR=, TOR-, IQ+, and IQ-), the following empirical asymmetric equation can be derived:

$$
\begin{aligned}
\Delta F D I_{i t}=\beta_{0 i}+ & \beta_{1 i} F D I_{i t-1}+\beta_{2 i}^{+} I Q_{t-1}^{+}+\beta_{2 i}^{-} I Q_{t-1}^{-}+\beta_{3 t}^{+} T O R_{t-1}^{+}+\beta_{3 t}^{-} T O R_{t-1}^{-}+\beta_{4 t} D I_{t-1}+\beta_{5 t} T O_{t-1} \\
& +\beta_{6 t} M_{t-1}+\beta_{7 t} I N F_{t-1} \\
& +\sum_{J=1}^{M-1} \gamma_{i J} \Delta F D I_{-} i_{i, t-J}+\sum_{J=0}^{N-1}\left(\gamma_{i j}^{+} \Delta I Q_{i, t-j}^{+}+\gamma_{i j}^{-} \Delta I Q_{i, t-j}^{-}\right) \\
& +\sum_{J=0}^{O-1}\left(\left(\delta_{i j}^{+} \Delta T O R_{i, t-j}^{+}+\delta_{i j}^{-} \Delta T O R_{i, t-j}^{-}\right)\right)+\beta_{4 t} D I_{t-1}+\beta_{5 t} T O_{t-1}+\beta_{6 t} M_{t-1}+\beta_{7 t} I N F_{t-1} \\
& +\varepsilon_{i t}
\end{aligned}
$$

where inst ${ }^{+} \&$ inst $^{-}$stand for the positive and negative shock of institutional quality, $\mathrm{TOR}^{+}$ and $T O R^{-}$Represents the positive and negative shock of tourism. The long-run coefficients are computed as ' $\Upsilon^{+}=\frac{-\beta_{2 i}^{+}}{\beta_{1 i}}, \Upsilon^{-}=\frac{-\beta_{2 i}^{-}}{\beta_{1 i}}, \mu^{+}=\frac{-\beta_{3 i}^{+}}{\beta_{1 i}}, \mu^{-}=\frac{-\beta_{3 i}^{-}}{\beta_{1 i}}$, respectively. These shocks are computed as positive and negative partial sum decomposition of institutional quality and tourism in the following ways:

$$
\begin{aligned}
& \left\{\begin{aligned}
I Q_{i}^{+} & =\sum_{k=1}^{t} \Delta I Q_{i k}^{+}=\sum_{K=1}^{T} \operatorname{MAX}\left(\Delta I Q_{i k}, 0\right) \\
\text { inst }_{i}^{-} & =\sum_{k=1}^{t} \Delta \text { inst }_{i k}^{-}=\sum_{K=1}^{T} \operatorname{MIN}\left(\Delta \text { inst }_{i k}, 0\right)
\end{aligned}\right.
\end{aligned}
$$

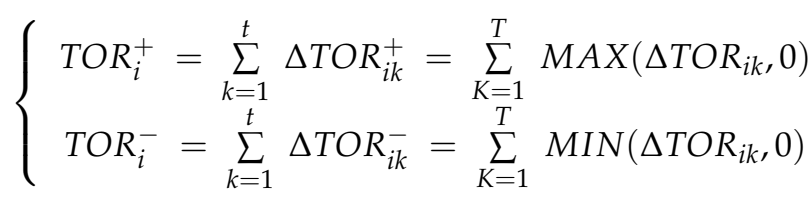


The error correction version of Equation (22) is as follows:

$$
\begin{aligned}
\Delta R E_{i t}=\tau_{1 i} \xi_{i t-1} & +\sum_{J=1}^{M-1} \gamma_{i j} \Delta R E_{i, t-J}+\sum_{J=0}^{N-1}\left(\gamma_{i j}^{+} \Delta F D_{i, t-j}^{+}+\gamma_{i j}^{-} \Delta F D_{i, t-j}^{-}\right)+\sum_{J=0}^{O-1}\left(\left(\delta_{i j}^{+} \Delta T O_{i, t-j}^{+}+\delta_{i j}^{-} \Delta T O_{i, t-j}^{-}\right)\right) \\
& +\sum_{J=0}^{P-1}\left(\mu_{i j}^{+} \Delta C F_{i, t-j}^{+}+\mu_{i j}^{-} \Delta C F_{i, t-j}^{-}\right)+\varepsilon_{i t}
\end{aligned}
$$

\subsection{Causality Test with Symmetric and Asymmetric with Toda-Yamamoto}

Gauging the possible directional causality between institutional quality, tourism, and FDI, this study applied the non-causality test proposed by Toda and Yamamoto [21]. Zapata and Rambaldi [152] claimed that Toda and Yamamoto's non-causality test outperforms the Granger causality test in certain situations. First, a non-causality test requires no cointegration characteristics in the system equation. Second, the MWALD test may examine existing causality between variables when the integration order is I (0) or I (1). Equation (26) showed symmetrical impacts between institutional quality and tourism.

$$
\begin{aligned}
X_{t i}=\alpha_{0}+\sum_{v=1}^{k} & \beta_{1 v} F D I_{t-v}+\sum_{j=k+1}^{d_{\max }} \beta_{2 j} F D I_{t-j}+\sum_{i=1}^{k} \gamma_{1 i} I Q_{t-i}+\sum_{j=k+1}^{d_{\max }} \gamma_{1 j} I Q_{t-j}+\sum_{i=1}^{k} \pi_{1 i} T O R_{t-i} \\
& +\sum_{j=k+1}^{d_{\max }} \pi_{1 j} T O R_{t-j}+\sum_{i=1}^{k} \tau_{1 i} D I_{t-i}+\sum_{j=k+1}^{d_{\max }} \tau_{1 j} D I_{t-j}+\sum_{i=1}^{k} \varphi_{1 i} M_{t-i}+\sum_{j=k+1}^{d_{\max }} \varphi_{1 j} M_{t-j} \\
& +\sum_{i=1}^{k} \delta_{1 i} T O_{t-i}+\sum_{j=k+1}^{d_{\max }} \delta_{2 j} T O_{t-j} \sum_{i=1}^{k} \delta_{1 i} I N F_{t-i}+\sum_{j=k+1}^{d_{\max }} \delta_{2 j} I N F_{t-j}+\varepsilon_{1 t}
\end{aligned}
$$

In the following, integrating the positive and negative shocks of institutional quality $\left[I Q_{i}^{+}, I Q_{i}^{-}\right]$and tourism $\left(T O R_{i}^{+}, T O R_{i}^{-}\right)$, the symmetric Equation (26) can be rewritten into an asymmetric Equation (27).

$$
\begin{aligned}
F D I_{t i}=\alpha_{0}+\sum_{v=1}^{k} & \beta_{1 v} F D I_{t-v}+\sum_{j=k+1}^{d_{\max }} \beta_{2 j} F D I_{t-j} \\
& +\left\{\sum_{i=1}^{k} \gamma_{1 i} I Q^{+} t-i+\sum_{j=k+1}^{d_{\max }} \gamma_{1 j} I Q^{+} t_{t-j}+\sum_{i=1}^{k} \gamma_{1 i} I Q^{-}{ }_{t-i}+\sum_{j=k+1}^{d_{\max }} \gamma_{1 j} I Q^{-}{ }_{t-j}\right\} \\
& +\left\{\sum_{i=1}^{k} \pi_{1 i} \mathrm{TOR}^{+} t-i+\sum_{j=k+1}^{d_{\max }} \pi_{1 j} T O R^{+}{ }_{t-j}+\sum_{i=1}^{k} \pi_{1 i} T O R^{-} t-i+\sum_{j=k+1}^{d_{\max }} \pi_{1 j} T O R^{-} t-j\right\} \\
& +\sum_{i=1}^{k} \tau_{1 i} D I_{t-i}+\sum_{j=k+1}^{d_{\max }} \tau_{1 j} D I_{t-j}+\sum_{i=1}^{k} \varphi_{1 i} M_{t-i}+\sum_{j=k+1}^{d_{\max }} \varphi_{1 j} M_{t-j}+\sum_{i=1}^{k} \delta_{1 i} T O_{t-i} \\
& +\sum_{j=k+1}^{d_{\max }} \delta_{2 j} T O_{t-j} \sum_{i=1}^{k} \delta_{1 i} I N F_{t-i}+\sum_{j=k+1}^{d_{\max }} \delta_{2 j} I N F_{t-j}+\varepsilon_{1 t}
\end{aligned}
$$

\section{Empirical Model Estimation and Discussion}

\subsection{Panel Unit Root, Cross-Section Dependence, and Cointegration Tests}

Now, we move to assess variables' order of integration that is the test of stationarity. Several first-generation unit-roots were performed in the study, namely, the LLC test [153], the IPS test proposed by Im et al. [154], the Breitung test proposed by Breitung [155], the Fisher-ADF proposed by Maddala and $\mathrm{Wu}$ [156] which have the null hypothesis that all the panel contains a unit root. Besides, the Lagrange multiplier (LM) test proposed by Hadri [157] has the null hypothesis that all panels are stationary; the first generation unit root test results are exhibited in Table 6. 
Table 6. First-generation Unit root test.

\begin{tabular}{|c|c|c|c|c|c|c|}
\hline & LLC & Breitlung & IPS & Fisher-ADF & Hadri & \multirow{2}{*}{ Order of Integration } \\
\hline \multicolumn{6}{|c|}{ PANEL-A: LOWER-INCOME COUNTRIES } & \\
\hline$F D I$ & $-2.468^{b}$ & $-1.763^{b}$ & $-12.70^{b}$ & $83.098^{b}$ & $7.313^{b}$ & $\mathrm{I}(0)=5$ \\
\hline$\triangle F D I$ & $-9.787^{b}$ & $-17.302^{b}$ & - & - & - & $\mathrm{I}(1)=2$ \\
\hline FDI_S & 0.85845 & 1.26841 & 54.8719 & 0.33113 & $7.392^{b}$ & $\mathrm{I}(0)=1$ \\
\hline$\Delta F D I \_S$ & $-8.85^{b}$ & $-2.874^{\mathrm{b}}$ & $-15.293^{b}$ & $334.724^{\mathrm{b}}$ & - & $\mathrm{I}(1)=4$ \\
\hline FDI_V & 4.711 & 7.22987 & 6.20027 & 49.0773 & $11.921^{b}$ & $\mathrm{I}(0)=1$ \\
\hline$\triangle F D I+\mathrm{V}$ & $-11.701^{b}$ & $-3.643^{b}$ & $-10.913^{b}$ & $302.364^{b}$ & - & $\mathrm{I}(1)=4$ \\
\hline IQ & -1.091 & 0.274 & -0.395 & 16.393 & $5.225^{\mathrm{a}}$ & $\mathrm{I}(0)=1$ \\
\hline$\widehat{\Delta \mathrm{IQ}}$ & $-3.254^{\mathrm{a}}$ & $-3.218^{a}$ & $-4.454^{\mathrm{a}}$ & $114.32^{\mathrm{a}}$ & $2.182^{b}$ & $\mathrm{I}(1)=5$ \\
\hline Tor & 0.018 & 0.782 & 0.475 & 11.078 & $5.598^{a}$ & $\mathrm{I}(0)=1$ \\
\hline$\Delta$ tor & $-3.481^{\mathrm{a}}$ & $-3.481^{\mathrm{a}}$ & $-3.481^{\mathrm{a}}$ & $-3.481^{\mathrm{a}}$ & $3.369^{\mathrm{a}}$ & $\mathrm{I}(1)=5$ \\
\hline DI & 0.418 & -0.27 & $-2.74^{\mathrm{a}}$ & $30.728^{a}$ & $2.683^{a}$ & $\mathrm{I}(0)=3$ \\
\hline$\Delta \mathrm{DI}$ & $-12.232^{a}$ & $-0.936^{\mathrm{a}}$ & $-6.841^{a}$ & $61.868^{a}$ & $2.641^{a}$ & $\mathrm{I}(1)=5$ \\
\hline $\mathrm{M}$ & $-2.888^{a}$ & 3.185 & $-4.893^{\mathrm{a}}$ & $53.049^{\mathrm{a}}$ & $6.584^{\mathrm{a}}$ & $\mathrm{I}(0) 4$ \\
\hline$\Delta \mathrm{M}$ & $-7.864^{\mathrm{a}}$ & $-9.67^{a}$ & $-3.165^{a}$ & $269.138^{a}$ & $10.025^{a}$ & $\mathrm{I}(1)=5$ \\
\hline $\mathrm{TO}$ & $-1.371^{b}$ & -0.752 & $-6.637^{a}$ & $64.879^{a}$ & $2.482^{\mathrm{a}}$ & $\mathrm{I}(0) 4$ \\
\hline$\Delta \mathrm{TO}$ & $-21.592^{a}$ & $-2.857^{\mathrm{a}}$ & $-16.245^{a}$ & $93.727^{a}$ & $7.391^{\mathrm{a}}$ & $\mathrm{I}(1)=5$ \\
\hline INF & 2.268 & 3.812 & -0.575 & 16.310 & $5.715^{\mathrm{a}}$ & $\mathrm{I}(0) 1$ \\
\hline$\Delta \mathrm{INF}$ & $-2.565^{a}$ & 1.175 & $-4.636^{\mathrm{a}}$ & $46.391^{a}$ & $7.694^{\mathrm{a}}$ & $\mathrm{I}(1)=4$ \\
\hline
\end{tabular}

Source: Authors' estimation. Note: the superscript a and b denoted the level of significance at $1 \%$ and $5 \%$, respectively.

Furthermore, we believe that data are cross-sectionally correlated since the lists of panel countries are geographically and economically connected. Therefore, we performed a cross-sectional dependency test, and the results are reported in Table 7, given that the variable under investigation has a cross-sectional dependency. So, one can assume that $F D I$, tourism, institutional quality, and domestic investment seem to exhibit some dynamisms common to all countries.

Table 7. Cross-section dependency test.

\begin{tabular}{cccc}
\hline & F_Inflows & F_Stock & F_Volatility \\
\hline LM $_{\text {BP }}$ (Breusch and Pagan, 1980) & $236.92^{\mathrm{a}}$ & $631.960^{\mathrm{a}}$ & $121.298^{\mathrm{a}}$ \\
LM & $170.311^{\mathrm{a}}$ & $73.41^{\mathrm{a}}$ & $87.846^{\mathrm{a}}$ \\
CD Pesaran (2004) & $6.954^{\mathrm{a}}$ & $4.822^{\mathrm{a}}$ & $8.415^{\mathrm{a}}$ \\
LM $_{\text {adj }}$ Pesaran et al. (2008) & $42.843^{\mathrm{a}}$ & $25.866^{\mathrm{a}}$ & $52.943^{\mathrm{a}}$ \\
\hline
\end{tabular}

Source: Authors' estimation. Note: the superscript a denoted the level of significance at $1 \%$ and $5 \%$, respectively.

With regards to the results of the cross-sectional dependency test and following empirical literature including, Gengenbach et al. [158] and Dogan and Aslan [159], we perform a two-panel unit root test, which is predominately applied due to the presence of cross-sectional dependency in the panel data that is augmented cross-sectional ADF $(C A D F)$ and CIPS unit root test proposed by Pesaran [142]. The results of the panel unit root tests are exhibited in Table 8. Results of panel unit root tests established mixed order of integration, that is, variables are integrated either at a level I (0) or/and after the first difference I (1). 
Table 8. Results of panel unit root test.

\begin{tabular}{ccccc}
\hline & \multicolumn{2}{c}{ CIPS } & \multicolumn{2}{c}{ CADF } \\
\hline & At Level & $\Delta$ & At Level & $\Delta$ \\
\hline FDI & -1.734 & $-5.319^{\mathrm{a}}$ & 2.122 & $-4.800^{\mathrm{a}}$ \\
FDI_S & -0.968 & $-6.094^{\mathrm{a}}$ & $-4.343^{\mathrm{a}}$ & $-4.343^{\mathrm{a}}$ \\
FDI_V & -2.099 & $-5.385^{\mathrm{a}}$ & 0.063 & $-3.942^{\mathrm{a}}$ \\
IQ & $-3.761^{\mathrm{a}}$ & $-5.944^{\mathrm{a}}$ & $-3.726^{\mathrm{b}}$ & $-8.006^{\mathrm{a}}$ \\
TOR & $-2.508^{\mathrm{b}}$ & $-5.902^{\mathrm{a}}$ & -0.828 & $-5.904^{\mathrm{a}}$ \\
DI & $-3.085^{\mathrm{b}}$ & $-6.905^{\mathrm{a}}$ & 1.094 & $-3.992^{\mathrm{a}}$ \\
M & $-5.045^{\mathrm{a}}$ & $-7.034^{\mathrm{a}}$ & $-3.223^{\mathrm{b}}$ & $4.225^{\mathrm{a}}$ \\
TO & -1.046 & $-3.297^{\mathrm{a}}$ & $-6.552^{\mathrm{a}}$ & $13.045^{\mathrm{a}}$ \\
INF & $-4.715^{\mathrm{a}}$ & $-6.190^{\mathrm{a}}$ & -1.262 & $-9.404^{\mathrm{a}}$ \\
\hline
\end{tabular}

Source: Authors' estimation. Note: the superscript of a and b indicates the level of significance at a $1 \%$ and $5 \%$ level, respectively.

In the following, the study performed a residual-based panel cointegration test proposed by Pedroni $[146,147]$ and Kao [148], assessing the possible long-run association between institutional quality, tourism, and FDI. The results of the panel cointegration test are reported in Table 9. Alluding to the outcomes, we can postulate the presence of a long-run equilibrium relationship between $F D I$, institutional quality, and tourism since the null hypothesis is rejected at a $1 \%$ level of significance. This verdict is valid for all empirical model estimations. The existence of a cointegrating equilibrium relationship between the variables paves the way for uncovering both the short- and long-run dynamics.

Table 9. Panel Cointegration Test.

\begin{tabular}{|c|c|c|c|}
\hline & Model-1 & Model-2 & Model-3 \\
\hline \multicolumn{4}{|c|}{ Panel-A: Padroni Cointegration } \\
\hline \multicolumn{4}{|c|}{ Common AR coefficients (within-dimension) } \\
\hline v-Statistic ${ }_{[}^{\text {weighted }}$ & $-5.815^{\mathrm{a}}$ & $6.429^{a}$ & $4.435^{\mathrm{a}}$ \\
\hline rho-Statistic $\left.{ }^{\text {weighted }}\right]$ & -0.398 & $-6.269^{a}$ & $3.400^{\mathrm{a}}$ \\
\hline PP-Statistic ${ }_{[}^{\text {weighted }}$ & $-3.112^{\mathrm{a}}$ & $-7.742^{\mathrm{a}}$ & -1.636 \\
\hline ADF-Statistic ${ }_{[}^{\text {weighted }}$ & $-4.282^{\mathrm{a}}$ & -3.851 & $-2.281^{a}$ \\
\hline v-Statistic & 0.072 & $5.906^{\mathrm{a}}$ & $5.026^{\mathrm{a}}$ \\
\hline rho-Statistic & $-2.828^{a}$ & $-7.438^{a}$ & -0.565 \\
\hline PP-Statistic & $-7.736^{\mathrm{a}}$ & $-18.104^{\mathrm{a}}$ & $-3.667^{\mathrm{a}}$ \\
\hline ADF-Statistic & 1.808 & 5.109 & -1.347 \\
\hline \multicolumn{4}{|c|}{ Individual AR coefficients (between-dimension) } \\
\hline Group rho-Statistic & 1.377 & $-5.141^{\mathrm{a}}$ & $-2.325^{a}$ \\
\hline Group PP-Statistic & $-3.054^{\mathrm{a}}$ & $-23.381^{a}$ & $-2.154^{\mathrm{a}}$ \\
\hline Group ADF-Statistic & $-8.764^{\mathrm{a}}$ & $-3.185^{a}$ & $-3.307^{\mathrm{a}}$ \\
\hline \multicolumn{4}{|c|}{ Panel-B: KAO estimation } \\
\hline ADF & $-3.531^{\mathrm{a}}$ & $-2.297^{\mathrm{a}}$ & $-3.434^{\mathrm{a}}$ \\
\hline
\end{tabular}

Source: Authors' estimation. Note: ${ }^{a}$ indicate levels of significance at a $1 \%$.

Additionally, the study performed the Westerlund-Durbin-Hausman panel cointegration test proposed by Westerlund [149], and test results are exhibited in Table 10. Model estimation produces two statistics: Group statistics based on panel homogeneity and Panel statistics based on panel heterogeneity report the summary results of the panel cointegration test. Regarding the associate $p$-value of test statistics, they are statistically significant at a1\% level of significance. These findings imply that inflows of $F D I$ will be affected by any changes in institutional quality, tourism, in the economy in the long run. 
Table 10. Result of Westerlund-Durbin-Hausman (2008) Panel Cointegration Test.

\begin{tabular}{cccc}
\hline Test & $\mathbf{( 1 )}$ & $\mathbf{( 2 )}$ & (3) \\
\hline D-H Group Statistic & $4.448^{\mathrm{a}}$ & $23.871^{\mathrm{a}}$ & $15.598^{\mathrm{a}}$ \\
D-H Panel Statistic & $17.934^{\mathrm{a}}$ & $4.943^{\mathrm{a}}$ & $6.142^{\mathrm{a}}$ \\
\hline
\end{tabular}

Source: Authors' estimation. Note: ${ }^{a}$ indicates level of significance at a $1 \%$ level.

Furthermore, the presence of a long-run relationship can also be assessed by considering the coefficient of ECT in panel PGM estimation. In order to establish a long-run association, the coefficient of ECT should be negative and statistically significant. Referring to the coefficients reported in Column (1) to Column (9), it is observable that all the coefficients are negative in sign and statistically significant at a $1 \%$ level. Therefore, we can conclusively postulate that institutional quality, tourism, and FDI move together in the long run.

\subsection{Results of Panel-ARDL (PGM) Estimations}

Table 11 displayed the results of PGM estimation, which includes the long-run and the short-run coefficients in panel-A and Panel-B, respectively. Getting insight into the tested nexus between institutional quality, tourism, and $F D I$, this study has performed nine empirical models based on various proxies for the dependent variable. The Study findings with FDI inflows as a percentage of GDP are reported in columns (1)-(3), in terms of FDI stock displayed in columns (4)-(6), and FDI volatility exhibited in columns (7)-(9).

Table 11. Estimates of Panel Error-Correction Model with PMG method.

\begin{tabular}{|c|c|c|c|c|c|c|c|c|c|}
\hline & \multicolumn{9}{|c|}{ Empirical Model Estimation } \\
\hline & (1) & (2) & (3) & (4) & (5) & (6) & (7) & (8) & (9) \\
\hline \multicolumn{10}{|c|}{ Panel-A: Long-run coefficients } \\
\hline$\beta$ & $0.440^{b}$ & - & $0.166^{\mathrm{b}}$ & $0.536^{\mathrm{a}}$ & - & $0.516^{\mathrm{a}}$ & $-0.031^{\mathrm{a}}$ & - & -0.246 \\
\hline$\mu$ & - & $0.240^{b}$ & $0.942^{\mathrm{a}}$ & - & 2.230 & $0.487^{\mathrm{a}}$ & - & $-0.413^{\mathrm{a}}$ & $-0.196^{\mathrm{a}}$ \\
\hline$\alpha$ & $1.584^{\mathrm{b}}$ & $1.273^{b}$ & $1.297^{b}$ & $0.336^{\mathrm{a}}$ & 0.946 & $0.384^{\mathrm{a}}$ & $0.518^{a}$ & $0.6113^{a}$ & $0.409^{\mathrm{a}}$ \\
\hline$\delta$ & $0.377^{\mathrm{b}}$ & $0.059^{\mathrm{a}}$ & $1.462^{b}$ & $0.203^{a}$ & $-0.230^{\mathrm{a}}$ & $0.147^{\mathrm{a}}$ & $-0.240^{\mathrm{a}}$ & $-0.339^{a}$ & $-0.581^{\mathrm{a}}$ \\
\hline$\zeta$ & $1.724^{\mathrm{a}}$ & $1.431^{\mathrm{b}}$ & $0.810^{\mathrm{b}}$ & $0.771^{\mathrm{a}}$ & $0.252^{\mathrm{a}}$ & $0.587^{\mathrm{a}}$ & $0.209^{\mathrm{a}}$ & $0.119^{a}$ & $0.985^{\mathrm{a}}$ \\
\hline$\lambda$ & $0.254^{\mathrm{a}}$ & $0.023^{a}$ & $0.033^{\mathrm{a}}$ & $-0.051^{\mathrm{a}}$ & $-0.175^{\mathrm{a}}$ & $-0.071^{\mathrm{a}}$ & $-0.181^{\mathrm{a}}$ & $-0.088^{a}$ & $-0.051^{a}$ \\
\hline \multicolumn{10}{|c|}{ Panel-B: short-run coefficient } \\
\hline ECT & $-0.473^{\mathrm{a}}$ & $-0.589^{a}$ & $-0.680^{\mathrm{a}}$ & $-0.163^{a}$ & $-0.205^{\mathrm{a}}$ & $-0.182^{a}$ & $-0.255^{\mathrm{a}}$ & $-0.261^{\mathrm{a}}$ & $-0.250^{\mathrm{a}}$ \\
\hline $\mathrm{D}(\mathrm{IQ})$ & $0.289^{b}$ & - & $0.092^{\mathrm{a}}$ & $-0.106^{\mathrm{a}}$ & - & $-0.104^{\mathrm{a}}$ & $0.445^{\mathrm{a}}$ & - & 0.473 \\
\hline TOR & - & $0.161^{b}$ & $0.124^{\mathrm{a}}$ & - & $-1.354^{a}$ & $-0.471^{\mathrm{a}}$ & - & 1.72 & 1.121 \\
\hline $\mathrm{D}(\mathrm{M})$ & $0.045^{*}$ & $0.112^{b}$ & $0.186^{\mathrm{a}}$ & -0.042 & $-0.115^{\mathrm{a}}$ & $-0.044^{\mathrm{a}}$ & $-0.017^{\mathrm{a}}$ & -0.053 & -0.028 \\
\hline $\mathrm{D}(\mathrm{INF})$ & $0.221^{c}$ & $0.297^{b}$ & $0.379^{a}$ & $0.054^{\mathrm{a}}$ & 0.093 & $0.052^{c}$ & $0.101^{c}$ & $0.1426^{b}$ & $0.196^{\mathrm{a}}$ \\
\hline $\mathrm{D}(\mathrm{TO})$ & 0.476 & $0.593^{c}$ & $0.411^{\mathrm{c}}$ & $0.024^{\mathrm{a}}$ & -0.024 & $0.042^{\mathrm{c}}$ & $-0.011^{\mathrm{c}}$ & $-0.056^{b}$ & $-0.129^{b}$ \\
\hline $\mathrm{D}(\mathrm{DI})$ & $0.373^{c}$ & $0.146^{c}$ & $0.0213^{b}$ & $0.027^{b}$ & $0.021^{\mathrm{C}}$ & $0.012^{b}$ & $0.105^{b}$ & $0.088^{b}$ & $0.073^{b}$ \\
\hline $\mathrm{C}$ & $-1.392^{b}$ & $-4.737^{b}$ & $-8.929^{b}$ & $0.373^{a}$ & $-1.232^{\mathrm{a}}$ & $0.075^{\mathrm{a}}$ & $-0.228^{b}$ & $0.044^{b}$ & $-1.403^{b}$ \\
\hline H-test ( $p$-value) & 0.982 & 0.623 & 0.872 & 0.554 & 0.552 & 0.211 & 0.831 & 0.612 & 0.223 \\
\hline
\end{tabular}

Source: Authors' estimation. Note: ${ }^{\mathrm{a} / \mathrm{b} / \mathrm{c}}$ indicates level of significant at a $1 \%, 5 \%$, and $10 \%$ level, respectively. ${ }^{*} p<0.05$.

The model estimation outcome is displayed in columns (1)-(3), where FDI inflows are treated as a dependent variable. In the long run, we observed that both institutional quality (a coefficient of 0.440 ) in column (1) and tourism (a coefficient of 0.240 ) in column (2) are positively associated with their respective empirical model. Furthermore, the empirical model outcome with the presence of both independent variables (see, column-(3)), it is apparent that tourism (a coefficient of 0.166) and institutional quality (a coefficient of 0.942) induced inflows of FDI with a positive attitude and their coefficients are statistically significant at a $1 \%$ level. As such, one can assume that in the long run, inflows of FDI in BMISTEC nations can be accelerated by offering a better institutional perspective and internationalization of tourism services. In the short-run (see, Panel-B, Columns (1)-(3)), the effects of institutional quality and tourism are positively linked to inflows of FDI. Considering the model output reported in Column (3), it is apparent that both institutional 
quality (a coefficient of 0.092) and tourism (a coefficient of 0.124) are positively connected with inflows of $F D I$.

The results are reported in columns (4) to (6), where FDI stock is considered a dependent variable. In the long run, institutional quality (a coefficient of 0.536) and tourism (a coefficient of 2.230) are positively associated with FDI inflows in terms of stock in their respective sole empirical assessment. Furthermore, referring to column (6), where both institutional quality and tourism are incorporated in the equation and unveiled positive effects, that is, institutional quality (a coefficient of 0.516) and tourism (a coefficient of 0.487 ), on FDI stocks. More specifically, if it is possible to implement a $10 \%$ acceleration in institutional quality and tourism, such an injection will result in $5.16 \%$ of $F D I$ stock flows due to the development of institutional quality and $4.87 \%$ due to tourism expansion. In the short run, the long-run equilibrium convergence is established in all tested empirical models, implying that the coefficients of ECT are negative and statistically significant. However, considering the short-run elasticities of institutional quality and tourism on FDI stock. The study findings suggested a negative association between them, but all the coefficients are statistically insignificant.

Finally, empirical model estimation with $F D I$ volatility as the dependent variable and the results are reported in Column (7) to (9). In the long run, in their respective equation, that is a sole model, both institutional quality (a coefficient of -0.031) and tourism (a coefficient of -0.413) exhibited a negative association with FDI volatility. Further, referring to results reported in column (9), we observed that both institutional quality (a coefficient of -0.246 ) and tourism (a coefficient of -0.196 ) play a negative role. More precisely, these findings suggest that a $10 \%$ development in institutional quality and tourism will reduce FDI volatility by $2.46 \%$ due to institutional quality and $1.96 \%$ due to tourism effects in the economy. Referring to the short-run effects reported in Panel-B, a statistically insignificant positive association between institutional quality, tourism, and FDI volatility is established.

For the control variables, money supply and trade openness play a positive role in increasing FDI inflows and FDI stock in the long run. However, insignificant effects are established in the case of FDI volatility. The coefficient of control variables, especially in the short-run, exhibited statistically insignificant except domestic investment. Domestic investment augments inflows of $F D I$ and FDI stocks, but insignificant effects are observed for FDI volatility.

\subsection{CS-ARDL Estimation}

In the following section, the study investigates the long-run and the short-run association between institutional quality, tourism, and FDI by performing CS-ARDL since the presence of cross-sectional dependency among researched variables. Table 12 exhibits the results of the long-run and short-run effects on FDI. Referring to long-run estimation (see, Panel-A), the noticeable findings are that both institutional quality and tourism are positively associated with $F D I$; these findings are also valid for all empirical model estimations. More specifically, the following results are reported in Columns (3), (6), and (9) with both institutional quality and tourism present in the equation. However, in the case of $F D I$ volatility as a dependent variable in the equation, the study findings established a negative association, that is, development in institutional quality and tourism will result in the stability in FDI inflows in the long run. 
Table 12. Short-run and long-run effects of institutional quality and Tourism on FDI.

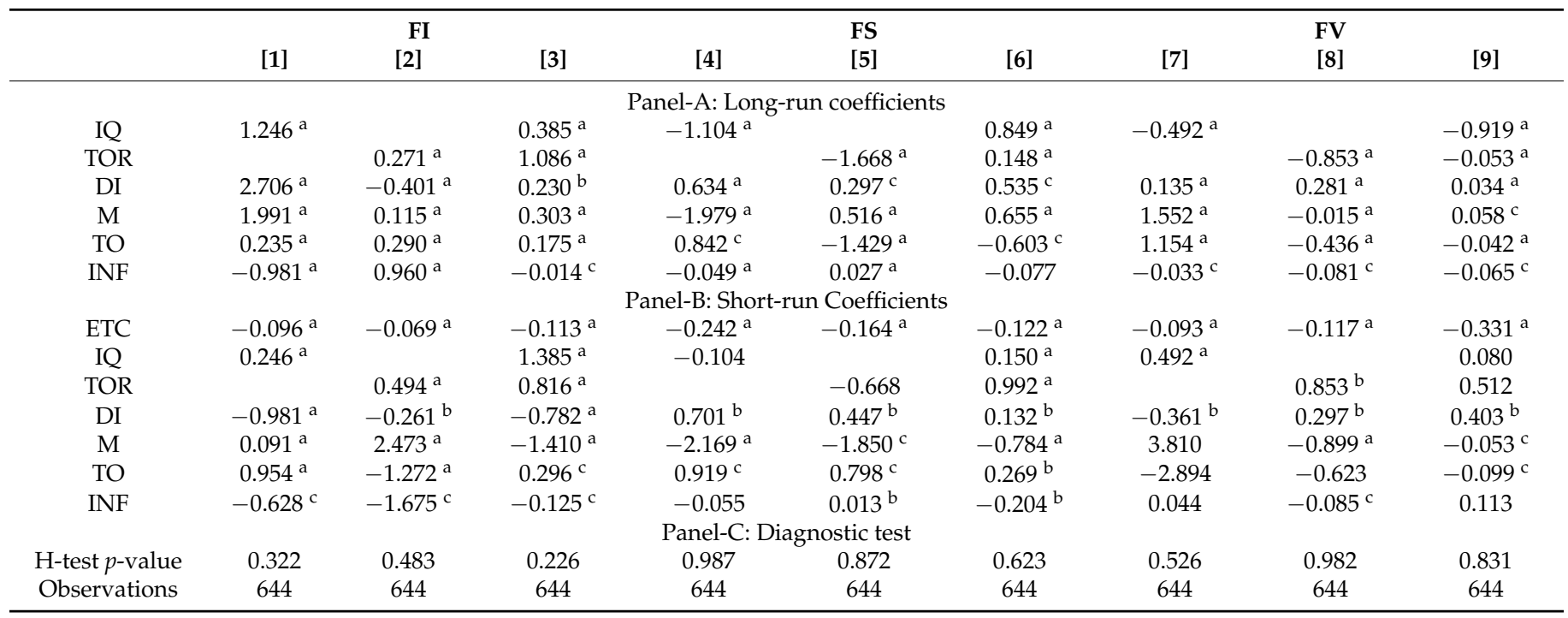

Source: Authors' estimation. Note: ${ }^{\mathrm{a} / \mathrm{b} / \mathrm{c}}$ indicates levels of significance at $1 \%, 5 \%$, and $10 \%$, respectively.

In the short run, the coefficients of error correction term, regardless of empirical model investigation, are negative in sign and statistically significant at a $1 \%$ level. These findings confirmed the presence of long-run convergence among the variables (see panel-B). Furthermore, analyzing the short-run magnitude running from the institutional quality and tourism, the study findings disclosed positive association (see panel-B, Columns (3), (6), and (9)). Specifically, 10\% development in institutional quality will result in further development in FDI inflows by $13.58 \%$, and tourism contributes to the process by $8.16 \%$; furthermore, FDI stock enhancement will be accelerated by $1.5 \%$ due to institutional quality and $9.92 \%$ assistance from tourism development. However, the short-run effects from the institutional quality and tourism on FDI volatility are statistically insignificant.

\subsection{Asymmetric Long-Run and Short-Run Effects Estimation}

In the following section, the study investigates the potential asymmetric association between institutional quality, tourism, and FDI by following a nonlinear framework introduced by shin. Using the nonlinear equation (see Equation (24)), we performed nine [09\} empirical models based on three proxy variables measuring FDI and the combined presence of independent variables in the equation. The results of nonlinear ARDL are presented in Table 13, consisting of long-run effects displayed in Panel-A, short-run coefficient inserted in Panel-B, and the result of the Wald test for assessing symmetry reported in Panel-C, respectively.

Table 13. Panel NARDL Estimation.

\begin{tabular}{|c|c|c|c|c|c|c|c|c|c|}
\hline \multirow{2}{*}{$\begin{array}{l}\text { Dependent } \\
\text { Variable } \rightarrow\end{array}$} & \multicolumn{3}{|c|}{ FDI Inflows } & \multicolumn{3}{|c|}{ FDI Stock } & \multicolumn{3}{|c|}{ FDI Volatility } \\
\hline & (1) & (2) & (3) & (4) & (5) & (6) & (7) & (8) & (9) \\
\hline \multicolumn{10}{|c|}{ Panel-A: Long-run coefficients } \\
\hline$\Upsilon^{+}$ & $0.066^{\mathrm{a}}$ & - & $0.131^{\mathrm{a}}$ & 0.271 & - & $0.253^{\mathrm{a}}$ & $-0.032^{\mathrm{a}}$ & - & $-0.053^{\mathrm{a}}$ \\
\hline$\Upsilon^{-}$ & $0.046^{\mathrm{a}}$ & - & $0.361^{\mathrm{a}}$ & -0.106 & - & $-0.021^{\mathrm{a}}$ & $-0.227^{\mathrm{a}}$ & - & $-0.651^{a}$ \\
\hline$\mu^{+}$ & - & $0.161^{\mathrm{a}}$ & $0.877^{\mathrm{a}}$ & - & $0.056^{\mathrm{a}}$ & $0.033^{\mathrm{a}}$ & - & $-0.002^{b}$ & $-0.004^{\mathrm{a}}$ \\
\hline$\mu^{-}$ & - & $0.909^{\mathrm{a}}$ & $0.226^{\mathrm{a}}$ & - & $0.124^{\mathrm{a}}$ & $0.881^{\mathrm{c}}$ & - & $-0.037^{b}$ & $-0.792^{a}$ \\
\hline M & $0.166^{\mathrm{a}}$ & $0.611^{b}$ & $0.836^{\mathrm{a}}$ & $0.713^{a}$ & $0.246^{\mathrm{a}}$ & $0.466^{c}$ & $-0.244^{\mathrm{a}}$ & $0.818^{b}$ & $0.673^{a}$ \\
\hline TO & $-0.816^{b}$ & $-0.206^{b}$ & $-0.76^{a}$ & $-0.509^{a}$ & $0.571^{b}$ & $-0.205^{c}$ & $0.119^{a}$ & $-0.377^{b}$ & $-0.521^{a}$ \\
\hline DI & $-0.112^{b}$ & $-0.272^{\mathrm{a}}$ & $-0.229^{a}$ & $-0.447^{\mathrm{a}}$ & $-0.725^{b}$ & $0.407^{\mathrm{c}}$ & $0.623^{a}$ & $0.242^{\mathrm{c}}$ & $-0.276^{c}$ \\
\hline INF & $0.461^{\mathrm{b}}$ & $0.014^{\mathrm{a}}$ & $-0.032^{a}$ & $1.069^{\mathrm{a}}$ & $0.097^{c}$ & $-0.272^{c}$ & $0.405^{b}$ & $-0.152^{\mathrm{s}}$ & $-0.065^{c}$ \\
\hline
\end{tabular}


Table 13. Cont.

\begin{tabular}{|c|c|c|c|c|c|c|c|c|c|}
\hline \multirow[t]{2}{*}{$\begin{array}{l}\text { Dependent } \\
\text { Variable } \rightarrow\end{array}$} & \multicolumn{3}{|c|}{ FDI Inflows } & \multicolumn{3}{|c|}{ FDI Stock } & \multicolumn{3}{|c|}{ FDI Volatility } \\
\hline & (1) & (2) & (3) & (4) & (5) & (6) & (7) & (8) & (9) \\
\hline \multicolumn{10}{|c|}{ Panel-B: Short-run coefficients } \\
\hline$\xi$ & -0.753 & -0.585 & -0.705 & $0.014^{a}$ & $-0.039^{a}$ & $-0.018^{a}$ & $-0.262^{a}$ & $-0.229^{a}$ & $-0.282^{a}$ \\
\hline $\mathrm{IQ}^{+}$ & $-0.143^{a}$ & - & $1.068^{\mathrm{a}}$ & $-0.331^{\mathrm{a}}$ & - & $0.213^{\mathrm{a}}$ & $-0.299^{a}$ & - & $0.042^{\mathrm{a}}$ \\
\hline $\mathrm{IQ}^{-}$ & $-1.924^{\mathrm{a}}$ & - & $-0.022^{a}$ & $-0.932^{\mathrm{a}}$ & - & $-0.682^{a}$ & $1.845^{\mathrm{a}}$ & - & $1.744^{\mathrm{c}}$ \\
\hline $\mathrm{TOR}^{+}$ & - & $2.004^{\mathrm{a}}$ & $0.195^{\mathrm{a}}$ & $-0.331^{\mathrm{a}}$ & $0.113^{\mathrm{a}}$ & $0.019^{\mathrm{a}}$ & - & $-0.016^{\mathrm{a}}$ & $0.113^{a}$ \\
\hline $\mathrm{TOR}^{-}$ & - & $0.329^{a}$ & $-0.683^{a}$ & $-0.932^{a}$ & $-0.421^{\mathrm{a}}$ & $-0.293^{a}$ & - & $0.613^{\mathrm{a}}$ & $-0.982^{a}$ \\
\hline $\mathrm{M}$ & $-0.042^{b}$ & $0.028^{b}$ & $0.018^{a}$ & $-0.139^{a}$ & $-0.016^{a}$ & $0.009^{a}$ & 0.114 & -0.015 & -0.007 \\
\hline $\mathrm{TO}$ & $0.365^{\mathrm{b}}$ & $0.322^{\mathrm{a}}$ & $0.195^{\mathrm{a}}$ & $0.079^{a}$ & $0.069^{b}$ & $0.133^{c}$ & 0.118 & 0.128 & $0.041^{\mathrm{a}}$ \\
\hline DI & $0.254^{b}$ & $0.912^{b}$ & $0.921^{\mathrm{a}}$ & $-0.392^{a}$ & $-0.031^{b}$ & $-0.145^{b}$ & -0.198 & $0.117^{\mathrm{a}}$ & $0.257^{c}$ \\
\hline INF & $0.129^{b}$ & $0.375^{c}$ & -0.164 & $0.008^{a}$ & $-0.018^{b}$ & $0.011^{\mathrm{c}}$ & 0.105 & $0.129^{a}$ & $-0.098^{c}$ \\
\hline $\mathrm{C}$ & $-0.043^{c}$ & $-5.67^{c}$ & $-0.023^{\mathrm{a}}$ & $-1.993^{b}$ & $-0.003^{b}$ & $-0.032^{\mathrm{a}}$ & $-0.479^{\mathrm{a}}$ & $-0.357^{\mathrm{a}}$ & 0.075 \\
\hline \multicolumn{10}{|c|}{ Panel-C: Long-run and short-run Symmetry test } \\
\hline$W_{L R}^{I Q}$ & $20.894^{\mathrm{a}}$ & $14.092^{\mathrm{a}}$ & $16.423^{\mathrm{a}}$ & $21.125^{a}$ & $20.793^{a}$ & $21.59^{a}$ & $25.482^{\mathrm{a}}$ & $17.951^{\mathrm{a}}$ & $19.517^{\mathrm{a}}$ \\
\hline$W_{L R}^{T O U R}$ & $13.359^{\mathrm{a}}$ & $20.613^{a}$ & $13.725^{a}$ & $22.964^{\mathrm{a}}$ & $19.924^{\mathrm{a}}$ & 19.378 & $14.326^{\mathrm{a}}$ & $18.508^{\mathrm{a}}$ & $12.225^{\mathrm{a}}$ \\
\hline$W_{S R}^{I Q}$ & $24.56^{\mathrm{a}}$ & $16.802^{a}$ & $19.846^{\mathrm{a}}$ & $12.684^{\mathrm{a}}$ & $20.486^{\mathrm{a}}$ & $15.121^{\mathrm{a}}$ & $15.755^{\mathrm{a}}$ & $24.759^{a}$ & $12.374^{\mathrm{a}}$ \\
\hline$W_{S R}^{T O U R}$ & $22.389^{a}$ & $24.614^{\mathrm{a}}$ & $15.759^{a}$ & $14.103^{a}$ & $25.796^{a}$ & $21.587^{\mathrm{a}}$ & $20.892^{a}$ & $14.433^{\mathrm{a}}$ & $17.699^{a}$ \\
\hline $\mathrm{H}$ - test ( $p$-value) & 0.605 & 0.949 & 0.704 & 0.518 & 0.958 & 0.732 & 0.737 & 0.574 & 0.241 \\
\hline $\mathrm{N}$ - test ( $p$-value) & 0.237 & 0.222 & 0.411 & 0.320 & 0.977 & 0.748 & 0.418 & 0.652 & 0.735 \\
\hline Log-likelihood & 230.14 & 289.641 & 277.91 & 265.06 & 176.07 & 134.97 & 536.978 & 119.05 & 209.81 \\
\hline
\end{tabular}

Source: Authors' estimation. Note: ${ }^{\mathrm{a} / \mathrm{b} / \mathrm{c}}$ indicates levels of significance at $1 \%, 5 \%$, and $10 \%$, respectively.

Referring to Panel-C, the results of the Wald test with the null hypothesis of both long-run and short-run symmetry. It is observable that the test statistics of the Wald test are statistically significant at a $1 \%$ level of significance that means asymmetric effects running from institutional quality and tourism towards FDI. These conclusions are applicable for all nine (09) tested empirical models.

Now, we analyze the potential effect and their association (see, Panel-A). The results are reported in columns (1) to (3), where FDI inflows as a percentage of GDP are treated as a dependent variable. Positive shocks in institution quality (a coefficient of 0.066 in column (1) and a coefficient of 0.131 in column 3 ) and negative shocks in institution quality (a coefficient of 0.046 in column (1) and a coefficient of 0.361 in column (3)) positively linked with inflows of FDI. The study findings suggest that both positive and negative shocks in institutional quality and tourism are critical for inflows of $F D I$ in the long run. However, the possessions of negative shocks are greater than the positive shocks in both variables.

On the other hand, observing the positive and negative shocks in tourism see, Column (2) and (3) we observed, see in column (2), that is, the positive (a coefficient of 0.161 ) and negative shocks (a coefficient of 0.909) and the results in column (3) positive shock (a coefficient of 0.877 ) and negative (a coefficient of 0.877 ), positive association with FDI. The study findings suggest that tourism recipients' increase or decrease will be critical for maintaining stability in FDI inflows in the long run. It is important to maintain the present state and put considerable effort into further development because any possible degradation might produce unwell full consequences.

Referring to the results exhibited in columns (4)-(6), FDI stock was treated as a dependent variable in the equation. In the long run, see column (6), positive shocks in institutional quality is positively linked (a coefficient of 0.253 ) with FDI stock, but negative shocks exhibit negative association (a coefficient of 0.021). These findings suggested that FDI stock inflows could be accelerated by adopting positive and negative institutional quality changes. However, the elasticity of positive innovation is greater than negative; therefore, policy formulation should understand the fact and do accordingly. In contrast, positive (a coefficient of 0.033 ) and negative (a coefficient of 0.881 ) shock in tourism disclosed a positive linkage with FDI stock. However, the negative shocks produce greater intensity than positive shocks in tourism. It refers that any deviation in tourism activities adversely affected the trend of FDI stock inflows in the economy. 
Considering the model output displayed in columns (7)-(9), FDI volatility was treated as a dependent variable. In the long run, positive and negative shocks in institutional quality (a coefficient of $-0.053,-0.651$ ) and tourism (a coefficient of $-0.004,-0.792$ ) are negatively associated with FDI volatility, and coefficients are statistically significant. Considering the elasticity of FDI volatility, negative shocks in institutional quality and tourism have a higher impact than positive shocks in variables. More specifically, a $10 \%$ variation in negative shocks in institutional quality and tourism will increase FDI volatility by $6.51 \%$ and 7.925 , respectively. On the other hand, $10 \%$ positive shocks in institutional quality and tourism can reduce FDI volatility by $0.531 \%$ and $0.04 \%$, respectively. Furthermore, the results reported in columns (7) and (8) also established a negative linkage with FDI volatility in both cases of positive and negative shocks in institutional quality and tourism.

In the short run, the coefficients of error correction terms exhibit negative signs and are statistically significant at a $1 \%$ level of significance. These findings suggest long-run convergence between institutional quality, tourism, and inflows of FDI in selected south Asian countries. Furthermore, referring to short-run elasticities, it is observable that positive shocks in institutional quality are positively linked to FDI, that is, a coefficient of 1.068 in column (3), a coefficient of 0.238 in column (6), and a coefficient of 0.042 in column (9) and all the coefficients are statistically significant. At the same time, the coefficients of negative shocks in institutional qualities are statistically insignificant except for FDI volatility (a coefficient of 1.744).

The positive and negative shocks in tourism established a mixed relationship with FDI. Both coefficients posted in column (3) displayed positive linkage with FDI inflows (a coefficient of 2.003 and a coefficient of 0.329). Results posted in column (6), reveal that positive shocks are positively associated (a coefficient of 0.019), and negative shocks are negatively caused (a coefficient of -0.293 ), and finally, tourism effects on FDI volatility exhibited mixed effects, but all the coefficients are statistically insignificant.

\subsection{Causality Analysis with Symmetry}

The results of the directional casualty test with symmetry effect from institutional quality and tourism are exhibited in Table 14.

Considering the results reported in Panel-A. The study findings established several causal relationships among research variables. However, we are primarily focusing on investigating casualty between FDI, IQ, and TOR. Regarding the desired causality, study findings established unidirectional causality running from institutional quality to tourism $[\mathrm{IQ} \rightarrow \mathrm{TOR}]$. Furthermore, the feedback hypothesis hold in assessing causality between institutional quality and FDI [IQ $\leftarrow \rightarrow F D I]$, and tourism and FDI [TOR $\leftarrow \rightarrow F D I]$.

The result is reported in Panel $-\mathrm{B}$, where FDI stock is treated as a proxy for the dependent variable. Similar to Panel-A, study findings established several causal relationships but considering the target relationship, that is, causality between FDI, IQ, and TOR. It has appeared that the Feedback hypothesis hold in explaining the causality between institutional quality and FDI [IQ $\leftarrow \rightarrow F D I]$, and tourism and FDI [TOR $\leftarrow F D I]$ but neutral effects appeared in the case of institutional quality and tourism [IQ $\neq$ TOU]. Finally, the causality results are exhibited in Panel-C, with FDI volatility as a dependent variable in the equation. The study findings established unidirectional casualty running form [TOR $\rightarrow X^{*}$ ], on the other hand, bidirectional causal relationship disclosed between institutional quality and FDI volatility $\left[\mathrm{IQ} \leftarrow \rightarrow \mathrm{X}^{*}\right]$.

Table 14. Causality test results with symmetry assumption.

\begin{tabular}{|c|c|c|c|c|c|c|c|c|}
\hline \multicolumn{9}{|c|}{ Panel-A: Dependent Variable as FDI Inflows } \\
\hline & $X^{*}$ & IQ & TOR & $\mathrm{M}$ & TO & DI & INF & $\mathrm{IQ} \leftarrow \rightarrow F D I ; \mathrm{TOR} \leftarrow \rightarrow F D I$ \\
\hline$X^{*}$ & - & $13.444^{\mathrm{a}}$ & $14.108^{a}$ & 3.18 & 1.478 & 3.285 & $8.381^{\mathrm{b}}$ & $\mathrm{INF} \rightarrow F D I ; \mathrm{INF} \rightarrow \mathrm{IQ}$ \\
\hline IQ & $12.781^{\mathrm{a}}$ & - & 1.265 & 2.265 & 5.19 & 2.122 & $7.962^{\mathrm{a}}$ & $\mathrm{IQ} \rightarrow \mathrm{TOR} ; \mathrm{M} \rightarrow \mathrm{TOR}$ \\
\hline TOR & $11.781^{\mathrm{a}}$ & $5.294^{c}$ & - & $11.168^{a}$ & $9.818^{a}$ & $14.453^{\mathrm{a}}$ & $9.051^{\mathrm{a}}$ & $\overrightarrow{\mathrm{DI}} \rightarrow \mathrm{TOR} ; \mathrm{INF} \rightarrow \mathrm{TOR}$ \\
\hline $\mathrm{M}$ & $6.391^{\mathrm{b}}$ & 3.458 & 0.92 & - & $47.344^{\mathrm{a}}$ & $29.571^{a}$ & $15.572^{\mathrm{a}}$ & $F D I \rightarrow \mathrm{M} ; \mathrm{TO} \leftarrow \rightarrow \mathrm{M}$ \\
\hline TO & 3.846 & $4.131^{c}$ & 3.534 & $9.014^{\mathrm{a}}$ & - & $13.659^{a}$ & 3.127 & $\mathrm{DI} \leftarrow \rightarrow \mathrm{M} ; \mathrm{INF} \leftarrow \rightarrow \mathrm{M}$ \\
\hline DI & 3.968 & $10.09^{a}$ & 1.74 & $36.345^{a}$ & $8.061^{\mathrm{b}}$ & - & 2.124 & $\mathrm{IQ} \rightarrow \mathrm{TO} ; \mathrm{DI} \leftarrow \rightarrow \mathrm{TO} ; \mathrm{IQ} \rightarrow \mathrm{DI} ;$ \\
\hline INF & 1.603 & 5.398 & 2.12 & $20.409^{a}$ & $17.337^{\mathrm{a}}$ & 7.328 & - & $\mathrm{IQ} \rightarrow \mathrm{INF} ; \mathrm{TO} \rightarrow \mathrm{INF} ; \mathrm{DI} \rightarrow \mathrm{INF}$ \\
\hline
\end{tabular}


Table 14. Cont.

\begin{tabular}{|c|c|c|c|c|c|c|c|c|}
\hline \multicolumn{9}{|c|}{ Panel-B: Dependent variable as FDI_stock } \\
\hline$X^{*}$ & - & $6.842^{c}$ & $14.068^{\mathrm{a}}$ & $7.712^{b}$ & $12.646^{\mathrm{a}}$ & 5.274 & 3.807 & $\mathrm{TOR} \leftarrow \rightarrow F D I ; \mathrm{M} \rightarrow F D I$ \\
\hline IQ & $11.137^{\mathrm{a}}$ & - & 2.96 & $5.461^{\mathrm{c}}$ & 2.942 & 3.114 & $9.447^{\mathrm{b}}$ & $\mathrm{TO} \leftarrow \rightarrow F D I ; F D I \leftarrow \rightarrow \mathrm{IQ}$ \\
\hline TOR & $22.572^{\mathrm{a}}$ & 4.005 & - & 3.556 & 3.568 & $9.645^{b}$ & 3.671 & $\mathrm{INF} \leftarrow \rightarrow \mathrm{IQ} ; \mathrm{M} \rightarrow \mathrm{IQ}$ \\
\hline M & 3.947 & 3.266 & 0.758 & - & $24.266^{\mathrm{a}}$ & $19.723^{\mathrm{a}}$ & $6.735^{c}$ & $\mathrm{DI} \rightarrow \mathrm{TOR} ; \mathrm{TO} \rightarrow \mathrm{M} ; \mathrm{DI} \leftarrow \rightarrow \mathrm{M}$; \\
\hline $\mathrm{TO}$ & $9.114^{b}$ & 2.284 & 3.254 & 4.377 & - & $12.209^{\mathrm{a}}$ & 1.392 & $\mathrm{INF} \leftarrow \rightarrow \mathrm{M} ; \mathrm{DI} \leftarrow \rightarrow \mathrm{TO}$ \\
\hline DI & 4.079 & 4.201 & 2.499 & $20.15^{\mathrm{a}}$ & $6.487^{c}$ & - & 5.208 & $F D I \rightarrow \mathrm{INF} ; \mathrm{TO} \rightarrow \mathrm{INF}$ \\
\hline INF & $10.878^{a}$ & $6.416^{c}$ & 2.892 & $42.769^{a}$ & $21.918^{\mathrm{a}}$ & $12.522^{\mathrm{a}}$ & - & $\mathrm{DI} \rightarrow \mathrm{INF}$ \\
\hline \multicolumn{9}{|c|}{ Panel-C: Dependent variable as FDI_volatility } \\
\hline$X^{*}$ & - & $14.166^{\mathrm{a}}$ & $9.127^{b}$ & 1.107 & 2.111 & 4.414 & $14.175^{a}$ & \multirow{7}{*}{$\begin{array}{c}\mathrm{IQ} \leftarrow \rightarrow \mathrm{X}^{*} ; \mathrm{TOR} \rightarrow \mathrm{X}^{*} ; \mathrm{INF} \rightarrow \\
\mathrm{X}^{*} ; \mathrm{IQ} \rightarrow \mathrm{TOR} ; \mathrm{TOR} \leftarrow \rightarrow \mathrm{DI} ; \\
\mathrm{TOR} \rightarrow \mathrm{M} ; \mathrm{TO} \rightarrow \mathrm{M} ; \mathrm{DI} \rightarrow \mathrm{M} ; \\
\mathrm{INF} \rightarrow \mathrm{M} ; \mathrm{TOR} \rightarrow \mathrm{TO} ; \\
\mathrm{DI} \leftarrow \rightarrow \mathrm{TO} ; \mathrm{TO} \rightarrow \mathrm{INF} ; \\
\mathrm{DI} \rightarrow \mathrm{INF}\end{array}$} \\
\hline IQ & $7.22^{b}$ & - & 1.713 & 2.92 & 3.245 & 0.264 & 3.189 & \\
\hline TOR & 0.542 & $8.035^{b}$ & - & 3.551 & 2.143 & $11.142^{\mathrm{a}}$ & 2.957 & \\
\hline $\mathrm{M}$ & 2.72 & 1.937 & $31.739^{a}$ & - & $8.801^{b}$ & $17.505^{\mathrm{a}}$ & $14.795^{a}$ & \\
\hline $\mathrm{TO}$ & 2.89 & 0.207 & $16.784^{\mathrm{a}}$ & 5.438 & - & $9.057^{c}$ & 3.36 & \\
\hline DI & 2.921 & 5.26 & $11.414^{\mathrm{a}}$ & $10.489^{a}$ & 5.035 & - & 4.543 & \\
\hline INF & 1.458 & 2.881 & 0.193 & 8.338 & 2.774 & $7.562^{b}$ & - & \\
\hline
\end{tabular}

Source: Authors' estimation. Note: the subscripts of ${ }^{\mathrm{a} / \mathrm{b} / \mathrm{c}}$ specify the significance levels at $1 \%, 5 \%$, and $10 \%$, respectively. ${ }^{*} p<0.05$.

In the following section, the causality test results considering asymmetry in institutional quality and tourism are exhibited in Table 15. Panel-A reports the results with FDI inflows as a dependent variable, Panel-B displays the results with FDI stock as dependent variables. Finally, Panel C reports the results with FDI volatility as a dependent variable, respectively. Referring to causality results, it appeared that several directional causalities are available, however focusing on the key motivation of the study, the summary results are exhibited in Table 16.

Table 15. Causality with Asymmetric assumption.

\begin{tabular}{|c|c|c|c|c|c|c|c|c|c|}
\hline 0 & $\mathbf{X}$ & $\mathrm{IQ}^{+}$ & $\mathbf{I Q}^{-}$ & TOR_P & TOR_N & DI & $\mathbf{M}$ & TO & INF \\
\hline \multicolumn{10}{|c|}{ Panel-A: Dependent variable as FDI inflows } \\
\hline$X$ & - & 3.805 & $7.841^{b}$ & 2.646 & $17.28^{\mathrm{a}}$ & 1.766 & 1.968 & $76.873^{a}$ & 4.299 \\
\hline $\mathrm{IQ}^{+}$ & $29.09^{a}$ & - & $6.767^{c}$ & 6.337 & $40.126^{\mathrm{a}}$ & 0.749 & 2.225 & $89.745^{a}$ & 5.588 \\
\hline $\mathrm{IQ}^{-}$ & $19.15^{\mathrm{a}}$ & 3.428 & - & 6.341 & $58.541^{\mathrm{a}}$ & 2.681 & 3.128 & $16.612^{\mathrm{a}}$ & 5.063 \\
\hline $\mathrm{TOR}^{+}$ & $26.615^{\mathrm{a}}$ & 4.29 & $6.865^{c}$ & - & $23.773^{a}$ & 1.123 & 1.526 & $15.817^{\mathrm{a}}$ & 4.1 \\
\hline $\mathrm{TOR}^{-}$ & $18.448^{\mathrm{a}}$ & 2.061 & $7.403^{c}$ & $6.277^{c}$ & - & 0.561 & 2.776 & $11.106^{\mathrm{a}}$ & 4.819 \\
\hline DI & $12.122^{a}$ & 2.951 & $13.449^{a}$ & 6.935 & $50.763^{a}$ & - & 2.321 & $14.216^{\mathrm{a}}$ & 4.823 \\
\hline M & $19.343^{\mathrm{a}}$ & $8.221^{b}$ & $13.441^{\mathrm{a}}$ & 3.777 & $34.051^{\mathrm{a}}$ & 0.101 & - & $9.231^{b}$ & $8.857^{b}$ \\
\hline $\mathrm{TO}$ & 4.205 & $12.276^{a}$ & $9.789^{b}$ & 4.849 & $19.268^{a}$ & 0.145 & 2.325 & - & 2.244 \\
\hline INF & $7.261^{b}$ & $8.242^{b}$ & $14.048^{\mathrm{a}}$ & 5.193 & $9.463^{\mathrm{a}}$ & 0.726 & 1.735 & $59.897^{a}$ & - \\
\hline \multicolumn{10}{|c|}{ Panel-B: Dependent variable as FDI stock } \\
\hline$x$ & - & $7.263^{c}$ & 3.41 & $10.673^{a}$ & 1.293 & $57.417^{\mathrm{a}}$ & $15.506^{\mathrm{a}}$ & 1.03 & $15.449^{\mathrm{a}}$ \\
\hline IQ_P & 2.265 & - & 3.152 & $15.008^{a}$ & 1.795 & $32.242^{\mathrm{a}}$ & 6.986 & 4.785 & 5.106 \\
\hline IQ_N & $13.148^{\mathrm{a}}$ & $13.659^{a}$ & - & $19.469^{\mathrm{a}}$ & $6.555^{c}$ & $17.196^{\mathrm{a}}$ & $61.623^{\mathrm{a}}$ & 4.792 & 4.122 \\
\hline TOR_P & 2.799 & 2.751 & 3.129 & - & 0.989 & $22.667^{\mathrm{a}}$ & $7.079^{\mathrm{c}}$ & 3.137 & 2.336 \\
\hline TOR_N & $11.413^{\mathrm{a}}$ & $12.494^{\mathrm{a}}$ & 1.544 & $16.603^{a}$ & - & $37.764^{\mathrm{a}}$ & $9.341^{b}$ & 2.086 & 1.465 \\
\hline $\mathrm{DI}$ & 2.423 & $11.734^{\mathrm{a}}$ & 3.036 & $11.009^{a}$ & 3.555 & - & $9.352^{b}$ & 0.72 & $9.254^{b}$ \\
\hline M & 1.693 & $19.702^{\mathrm{a}}$ & 5.688 & $13.217^{a}$ & 2.327 & 39.595 & - & 3.37 & $20.641^{a}$ \\
\hline TO & 2.504 & $12.326^{a}$ & $6.187^{c}$ & $9.337^{\mathrm{a}}$ & 5.178 & 36.819 & $7.344^{\mathrm{c}}$ & - & 3.337 \\
\hline INF & 3.613 & $12.307^{\mathrm{a}}$ & 4.947 & $11.577^{\mathrm{a}}$ & $6.658^{c}$ & 51.635 & $45.284^{\mathrm{a}}$ & 4.426 & - \\
\hline \multicolumn{10}{|c|}{ Panel-C: Dependent variable as FDI Volatility } \\
\hline$x$ & - & $13.326^{\mathrm{a}}$ & $11.314^{\mathrm{a}}$ & $19.094^{\mathrm{a}}$ & $38.726^{a}$ & $16.104^{\mathrm{a}}$ & 0.257 & 6.664 & 1.792 \\
\hline IQ_P & $16.341^{\mathrm{a}}$ & - & $14.835^{\mathrm{a}}$ & $13.521^{\mathrm{a}}$ & $12.196^{\mathrm{a}}$ & $18.102^{\mathrm{a}}$ & 0.145 & $16.34^{\mathrm{a}}$ & 1.721 \\
\hline IQ_N & $15.808^{a}$ & $16.608^{a}$ & - & $15.587^{\mathrm{a}}$ & $19.349^{\mathrm{a}}$ & $68.951^{a}$ & 0.287 & $9.597^{\mathrm{b}}$ & 0.864 \\
\hline TOR_P & $14.352^{\mathrm{a}}$ & $38.748^{\mathrm{a}}$ & $8.323^{a}$ & - & $14.375^{\text {a }}$ & $48.296^{\mathrm{a}}$ & 0.06 & $13.516^{\mathrm{a}}$ & 2.185 \\
\hline TOR_N & $14.215^{\mathrm{a}}$ & $15.577^{a}$ & $15.535^{a}$ & $16.426^{a}$ & - & $55.822^{a}$ & 0.212 & $8.507^{b}$ & 0.455 \\
\hline DI & $19.158^{a}$ & $16.339^{a}$ & $15.505^{a}$ & $18.929^{a}$ & $72.046^{a}$ & - & 0.337 & 4.59 & 3.828 \\
\hline M & 4.047 & $23.96^{\mathrm{a}}$ & $13.157^{a}$ & $12.767^{a}$ & $18.268^{a}$ & $94.587^{\mathrm{a}}$ & - & 4.623 & 2.861 \\
\hline $\mathrm{TO}$ & $10.324^{\mathrm{a}}$ & $17.805^{a}$ & $18.019^{a}$ & $14.029^{\mathrm{a}}$ & $27.047^{\mathrm{a}}$ & $89.151^{a}$ & 0.292 & - & 1.417 \\
\hline INF & $15.617^{a}$ & $15.336^{a}$ & $27.007^{a}$ & $11.252^{\mathrm{a}}$ & $57.008^{a}$ & $82.368^{a}$ & 0.274 & $12.211^{\mathrm{a}}$ & - \\
\hline
\end{tabular}


Table 16. Summary results of causality test.

\begin{tabular}{cccc}
\hline Causality & {$[1]$} & {$[2]$} & {$[3]$} \\
\hline$F D I \leftarrow \neq \rightarrow \rightarrow \mathrm{IQ}^{+}$ & $F D I \rightarrow \mathrm{IQ}^{+}$ & $\mathrm{IQ}^{+} \rightarrow F D I$ & $F D I \leftarrow \rightarrow \mathrm{IQ}^{+}$ \\
$\mathrm{IQ}^{+} \leftarrow \neq \rightarrow F D I$ & $F D I \leftarrow \rightarrow \mathrm{IQ}^{-}$ & $F D I \leftarrow \rightarrow \mathrm{IQ}^{-}$ \\
$F D I \leftarrow \neq \rightarrow \mathrm{IQ}^{-}$ & $F D I \leftarrow \rightarrow \mathrm{IQ}^{-}$ & & \\
$\mathrm{IQ}^{-} \leftarrow \neq \rightarrow F D I$ & $F D I \rightarrow \mathrm{TOR}^{+}$ & $\mathrm{TOR}^{+} \rightarrow F D I$ & $F D I \leftarrow \rightarrow \mathrm{TOR}^{+}$ \\
$F D \leftarrow \neq \rightarrow \mathrm{TOR}^{+}$ & $F D I \leftarrow \rightarrow \mathrm{TOR}^{-}$ & $F D I \rightarrow \mathrm{TOR}^{-}$ & $F D I \leftarrow \rightarrow \mathrm{TOR}^{-}$ \\
$\mathrm{TOR}^{+} \leftarrow \neq \rightarrow F D I$ & $F D I \leftarrow \neq \rightarrow \mathrm{TOR}^{-}$ & &
\end{tabular}

\section{Discussion}

Tourism is quickly becoming one of the most important businesses in many nations. It is primarily owing to its significant contribution to foreign exchange inflows, national income, and job possibilities, all of which have a significant economic effect on the individual nations. Refers to tourism-led foreign capital investment, the study documented a positive statistically significant association that is tourism positively assists in increasing the inflows of FDI in the economy. Our study findings align with existing literature see, for instance, Tomohara [31], Samimi, Sadeghi, and Sadeghi [29], and Perić and Radić [32]. Salleh, Othman, and Sarmidi [40] investigated the impact of tourism development on FDI inflows in the south Asian economy by employing ARDL. The study documented the long-run association between tourism development and growth in FDI. Moreover, the causality test established unidirectional causality running from tourism to FDI. The study of Siddiqui and Siddiqui [37] revealed unidirectional causality between tourism and FDI in Pakistan. The study advocated that effective tourism policy implementation can accelerate foreign capital investment in the economy.

Selvanathan, Selvanathan and Viswanathan [52] investigated the dynamic connection between tourism and FDI in India from 1995-2007 using quarterly statistical data under VAR estimation. The results indicated a unidirectional causal relationship between FDI and tourism and advocated that FDI attraction accelerated the development of foreign tourism in India's economy during the past decade. Khoshnevis Yazdi, Homa Salehi, and Soheilzad [46] established that foreign direct investment substantially affects tourist development in developing nations' economies. Inbound tourism generates export income, but it also creates jobs in the service sector via FDI because of tourist-related investment. Thus, to promote inbound tourism, it is necessary first to determine the nature of the connection between inbound tourism and FDI, as well as whether inward FDI flows only to tourism-related sectors, before formulating a more effective strategy based on the degree of correlation.

The growing interest in institutional and political development economics issues has resulted in detailed research on the factors influencing institutional quality [160]. The current study investigated the nexus of institutional quality-led tourism and exposed positive connections in empirical assessment, which is in line with Delgado and McCloud [161], Kim and Choi [162], Qamruzzaman, Tayachi, Mehta, and Ali [18]. Because of good institutional quality, the foreign direct investment (FDI) inflows are strong, and foreign direct investment $(F D I)$ volatility is low. On the other side, there are drivers of FDI outflows that are detrimental, such as corruption and institutional distance between the home and host nations. Quality institutions augmented inflows of FDI in the economy in three different manners. First, strong institutions improve productivity potential, which may attract international investment. Second, a dysfunctional institutional framework may drive up the cost of conducting business. For instance, corruption may discourage investment by increasing the cost of conducting business [163]. Third, FDI is subject to uncertainty, particularly uncertainty caused by inefficient governance, since it entails a large sunk cost. 
For instance, imprecise contract enforcement may raise uncertainty about future rewards, thus discouraging investment from foreign soil.

\section{Conclusions}

The prominent role of FDI is extensively investigated in empirical studies and the key determinants for accelerating the inflows of $F D I$, especially for developing countries. The motivation of the study is to unleash the fresh evidence regarding the nexus between institutional quality, tourism, and FDI in BIMSTEC nations during the period 1996Q1-2018Q4. Several econometric methodologies were applied including, panel-ARDL, CS-ARDL, Nonlinear-ARDL, and directional casualty investigated following Toda and Yamamoto [21] with the incorporation of both symmetry and asymmetry effects of institutional quality and tourism. The key findings of this study are reported below:

First, the study began with established variables order of integration by applying both first and second-generation panel unit root tests. The study established mixed order integration, that is, few variables are integrated at a level, and few become stationary after the first difference. Furthermore, a cross-sectional dependency test confirmed the presence of common dynamism among the selected variables.

Second, the study findings with Panel-ADRL confirmed the long-run positive association between institutional qualities, tourism, and inflows of FDI. The study findings suggest that further development in institutional quality and tourism activities will result in a positive way in the economy that induces foreign investors and increase possibilities for receiving additional FDI. These studies' findings are in line with Turan Katircioglu et al. [33]; Perić and Radić [32]; Khoshnevis Yazdi, Nateghian and Sheikh Rezaie [67]; Buchanan, Le, and Rishi [19]; Jushi et al. [164]. About CS-ARDL, the study findings also ascertain positive relations between institutional quality, tourism, and inflows of FDI in BIMSTEC nations, especially in the long run. In respective studies, Alfaro et al. [165] and Bénassy-Quéré, Coupet, and Mayer [103] have argued that the investors prefer to locate the environments of cases where property rights are well protected and the actors are the least corrupt as well that they require a high degree of political stability. Considering an empirical model with FDI stocks and FDI volatility as a dependent variable, the study findings revealed positive effects from the institutional quality and tourism towards FDI stock and negative impact towards FDI volatility, especially in the long run. These findings are applicable in both empirical models under panel-ARDL and CS-ARDL.

Third, the study findings with the nonlinear framework of assessing the asymmetric effects, i.e., positive and negative shocks in institutional quality and tourism on FDI. Referring to the results of the Wald test to establish possible asymmetric effects on both the long run and short run. The study findings revealed a long-run asymmetric relationship between institution quality, tourism, and FID, which applies to all models. These findings suggest that in the long run, the movement of the effects of each variable might not experience by other variables in the linear form, i.e., increasing independent variables may not result in the same progress in the dependent variable.

Fourth, the results of directional causality among research variables with symmetry and asymmetry effects of institutional quality and tourism in the equation. Concerning the traditional casualty test, i.e., symmetric framework, the study findings hold a feedback hypothesis explaining the relationship between institutional quality, tourism, and FDI. The study findings support existing empirical literature including, Chowdhury and Mavrotas [98]; Shah, Ahmad and Ahmed [77]; Arain, Han, Sharif, and Meo [43]. Furthermore, causality tests with the asymmetry of institutional quality and tourism. We observed that the feedback hypothesis explains the casualty between negative shocks in institutional quality and tourism and inflows of FDI and FDI stock. However, unidirectional causality is also revealed i.e., FDI inflows to positive shocks in institutional quality and positive shocks in institutional quality to FDI stock. On the other hand, referring to the asymmetry effect of tourism and FDI, findings divulged unidirectional causality running from FDI 
to positive shocks in tourism and feedback hypothesis is established between a negative shock in tourism and inflows of $F D I$.

Understanding the study findings, we also proposed the following policy recommendations for future guidance. First, institutional quality tourism emerged as a strategically critical factor for the economy, especially the decision about FDI. Policy formulation, therefore, and the promotional, strategic decision-making process by the government and private institutions have to put considerable attention on the present state of institutional quality and tourism in respective countries. Second, countries should use financial and tax incentives, as well as attractive rates to attract FDI. Reducing complex procedures (bureaucracy) and defining clear FDI policies in tourism is an important part of the process. Local authorities can also help indirectly to promote FDI by providing basic infrastructures free of cost to the investor.

The present study possesses certain limitations in terms of data aggregation and economical estimation. For institutional quality, the study considered an index derived from WGI information. Nonetheless, taking other measures might produce diverse findings. Inclusion of other variables such as Human capital development, economic policy uncertainty, and financial volatility can robust the estimation and bring another angle in empirical relationships.

Author Contributions: Conceptualization, Y.Y. and M.Q.; Data curation, Y.Y. and M.Q.; Formal analysis, M.Z.R. and S.K.; Funding acquisition, M.Q.; Methodology, Y.Y. and M.Z.R.; Writing-original draft, M.Q., M.Z.R. and S.K.; Writing-review \& editing, Y.Y., M.Q., M.Z.R. and S.K. All authors have read and agreed to the published version of the manuscript.

Funding: This research received no external funding.

Institutional Review Board Statement: Not applicable.

Informed Consent Statement: Not applicable.

Data Availability Statement: Att the data used in the study are available in public domin sucs as World Developent Indicator, International financial statistis.

Acknowledgments: We would like to thank the three anonymous reviewers for the critical and constructive suggestions, and due to so, we finally revised and reconstructed entire manuscripts. Furthermore, we are also grateful to the editor-in-chief and assistant editor for their kind consideration during the revision process. Furthermore, we would like to give our sincere gratitude to Amra Sabic-El-Rayess, Alex Eble, and Judith Scott-Clayton. With extraordinary patience and consistent encouragement, they gave us great help by providing the necessary materials, advice of great value, and inspiration of new ideas during study at Teachers College, Columbia University.

Conflicts of Interest: The authors declare no conflict of interest.

\section{References}

1. Quazi, R. Economic freedom and foreign direct investment in East Asia. J. Asia Pacific Econ. 2007, 12, 329-344. [CrossRef]

2. Blomstrom, M.; Lipsey, R.E.; Zejan, M. What explains the growth of developing countries? Converg. Prod. Cross Nat. Stud. Histor. Evid. 1994, 9, 243-259.

3. Ajayi, S.I. FDI and Economic Development in Africa; ADB/AERC International: New York, NY, USA, 2006.

4. Agbloyor, E.K.; Abor, J.; Adjasi, C.K.D.; Yawson, A. Exploring the causality links between financial markets and foreign direct investment in Africa. Res. Int. Bus. Financ. 2013, 28, 118-134. [CrossRef]

5. Soumaré, I.; Tchana Tchana, F. Causality between FDI and financial market development: Evidence from emerging markets. World Bank Econ. Rev. 2015, 29, S205-S216. [CrossRef]

6. Tsagkanos, A.; Siriopoulos, C.; Vartholomatou, K. Foreign direct investment and stock market development. J. Econ. Stud. 2019, 26, 178-185. [CrossRef]

7. Noorbakhsh, F.; Paloni, A.; Youssef, A. Human capital and FDI inflows to developing countries: New empirical evidence. World Dev. 2001, 29, 1593-1610. [CrossRef]

8. Blomstrom, M.; Kokko, A. Human Capital and Inward FDI; Centre for Economic Policy Research: London, UK, 2003.

9. Dorozynska, A.; Dorozynski, T. Human capital and FDI in central and eastern europe. Manag. Glob. Transit. 2015, 13, 151. 
10. Greenberg, J.; Mollick, E. Leaning in or leaning on? Gender, homophily, and activism in crowdfunding (SSRN Working Paper No. 2462254). Acad. Manag. Proc. 2015. Available online: https: / repository.upenn.edu/cgi/viewcontent.cgi? article=1294\&context= mgmt_papers (accessed on 3 September 2021). [CrossRef]

11. Crotti, S.; Cavoli, T.; Wilson, J.K. The impact of trade and investment agreements on Australia's inward FDI flows. Aust. Econ. Pap. 2010, 49, 259-275. [CrossRef]

12. Chung, K. Foreign debt, foreign direct investment and volatility. Int. Econ. J. 2010, 24, 171-196. [CrossRef]

13. Kosekahyaoglu, L. A comparative analysis of FDI in Turkey and the CEECs: Is there any link between FDI and trade? J. Bus. Econ. Manag. 2006, 7, 183-200. [CrossRef]

14. De Angelo, C.F.; Eunni, R.V.; Fouto, N.M.M.D. Determinants of FDI in emerging markets: Evidence from Brazil. Int. J. Commer. Manag. 2010, 20, 203-216. [CrossRef]

15. Liargovas, P.G.; Skandalis, K.S. Foreign direct investment and trade openness: The case of developing economies. Soc. Indic. Res. 2012, 106, 323-331. [CrossRef]

16. Singhania, M.; Gupta, A. Determinants of foreign direct investment in India. J. Int. Trade Law Policy 2011, 10, 64-82. [CrossRef]

17. Anyanwu, J.C.; Yameogo, N.D. What drives foreign direct investments into West Africa? An empirical investigation. Afr. Dev. Rev. 2015, 27, 199-215. [CrossRef]

18. Qamruzzaman, M.; Tayachi, T.; Mehta, A.M.; Ali, M. Do international capital flows, institutional quality matter for innovation output: The mediating role of economic policy uncertainty. J. Open Innov. Technol. Market Complex. 2021, 7, 141. [CrossRef]

19. Buchanan, B.G.; Le, Q.V.; Rishi, M. Foreign direct investment and institutional quality: Some empirical evidence. Int. Rev. Financ. Anal. 2012, 21, 81-89. [CrossRef]

20. Shin, Y.; Yu, B.; Greenwood-Nimmo, M. Modelling asymmetric cointegration and dynamic multipliers in a nonlinear ARDL framework. In Festschrift in Honor of Peter Schmidt; Springer: Berlin, Germany, 2014; pp. 281-314.

21. Toda, H.Y.; Yamamoto, T. Statistical inference in vector autoregressions with possibly integrated processes. J. Econom. 1995, 66, 225-250. [CrossRef]

22. Fauzel, S. FDI and tourism futures: A dynamic investigation for a panel of small island economies. J. Tour. Futures 2021, 7, 98-110. [CrossRef]

23. Jena, N.R.; Sethi, N. Foreign capital and growth nexus revisited: Empirical evidence from South Asian countries. Transnat. Corp. Rev. 2021, 13, 269-292. [CrossRef]

24. Sokhanvar, A. Does foreign direct investment accelerate tourism and economic growth within Europe? Tour. Manag. Perspect. 2019, 29, 86-96. [CrossRef]

25. Fereidouni, H.G.; Al-mulali, U. The interaction between tourism and FDI in real estate in OECD countries. Curr. Issues Tour. 2014, 17, 105-113. [CrossRef]

26. Udemba, E.N. Triangular nexus between foreign direct investment, international tourism, and energy consumption in the Chinese economy: Accounting for environmental quality. Environ. Sci. Pollut. Res. 2019, 26, 24819-24830. [CrossRef]

27. Lea, J. Tourism and Development in the Third World; Routledge: London, UK, 2006.

28. Schroenn, J.; Tecle, Y. The contribution of HRD to tourism-led development in an African context: Economics. S. Afr. J. Econ. Manag. Sci. 2006, 9, 444-457.

29. Samimi, A.J.; Sadeghi, S.; Sadeghi, S. The relationship between foreign direct investment and tourism development: Evidence from developing countries. Inst. Econ. 2017, 5, 59-68.

30. Sinclair, M.; Stabler, M. The Economics of Tourism, Advances in Tourism; Routledge: London, UK; New York, NY, USA, 2002.

31. Tomohara, A. Japan's tourism-led foreign direct investment inflows: An empirical study. Econ. Model. 2016, 52, 435-441. [CrossRef]

32. Perić, J.; Radić, M.N. FDI-led tourism growth hypothesis: Empirical evidence from Croatian tourism. Eur. J. Tour. Hospital. Recreat. 2016, 7, 168-175. [CrossRef]

33. Katircioglu, S.T.; Kahyalar, N.; Benar, H. Financial Development, Trade and Growth Triangle: The Case of India. Int. J. Soc. Econ. 2007, 45, 586-598.

34. Kaur, H.; Sarin, V. Causality relationship between GDP, FDI, tourism: Empirical evidence from India. Int. J. Appl. Bus. Econ. Res. 2016, 14, 247-255.

35. Vorley, B. Risks and opportunities in attracting foreign direct investment in the agrifood sector: The case of supermarkets. In Responsible Enterprise, Foreign Direct Investment and Investment Promotion: Key Issues in Attracting Investment for Sustainable Development; International Institute for Environment and Development, JSTOR: New York, NY, USA, 2008 ; p. 53.

36. Ivanovic, Z.; Baresa, S.; Bogdan, S. Influence of FDI on tourism in Crostia. UTMS J. Econ. 2011, 2, 21-28.

37. Siddiqui, F.; Siddiqui, D.A. Causality between Tourism and Foreign Direct Investment: An Empirical Evidence from Pakistan. Asian J. Econ. Modell. 2019, 7, 27-44. [CrossRef]

38. Arain, H.; Sharif, A.; Akbar, B.; Younis, M.Y. Dynamic connection between inward foreign direct investment, renewable energy, economic growth and carbon emission in China: Evidence from partial and multiple wavelet coherence. Environ. Sci. Pollut. Res. 2020, 27, 40456-40474. [CrossRef] [PubMed]

39. Satrovic, E. Financial development and human capital in Turkey: ARDL approach. Kapadokya Akad. Bakış 2017, 1, 1-15.

40. Salleh, N.H.M.; Othman, R.; Sarmidi, T. An analysis of the relationships between tourism development and foreign direct investment: An empirical study in elected major Asian countries. Int. J. Bus. Soc. Sci. 2011, 2, 17. 
41. Khoshnevis Yazdi, S.; Shakouri, B. The effect of renewable energy and urbanization on $\mathrm{CO}_{2}$ emissions: A panel data. Energy Sour. Part B Econ. Plann. Policy 2018, 13, 121-127. [CrossRef]

42. Chang, S.-C.; Chang, H.-F. Same Trade Openness Yet Different Environmental Quality-But Why? J. Int. Commer. Econ. Policy 2020, 11, 2050002. [CrossRef]

43. Arain, H.; Han, L.; Sharif, A.; Meo, M.S. Investigating the effect of inbound tourism on FDI: The importance of quantile estimations. Tour. Econ. 2019, 26, 682-703. [CrossRef]

44. Katircioglu, S. The Bounds Test to the Level Relationship and Causality Between Foreign Direct Investment and International Tourism: The Case of Turkey; University of West Bohemia: Plzeň, Chech Republic, 2011.

45. Satrovic, E.; Muslija, A. Foreign direct investments and tourism: Empirical evidence from Turkey. In Proceedings of the ICPESS (International Congress on Politic, Economic and Social Studies), Istanbul, Turkey, 9-11 November 2017.

46. Khoshnevis Yazdi, S.; Homa Salehi, K.; Soheilzad, M. The relationship between tourism, foreign direct investment and economic growth: Evidence from Iran. Curr. Issues Tour. 2017, 20, 15-26. [CrossRef]

47. Sanford, D.M., Jr.; Dong, H. Investment in familiar territory: Tourism and new foreign direct investment. Tour. Econ. 2000, 6, 205-219. [CrossRef]

48. Tiwari, A.K. Tourism, Exports and FDI as a Means of Growth: Evidence from four Asian Countries. Rom. Econ. J. 2011, 14, 40.

49. Muckley, C.B. Terrorism, Tourism and FDI: Estimating a Lower Bound on the Peace Dividend in Northern Ireland; University College Dublin: Dublin, Ireland, 2010.

50. Buckley, P.; Geyikdagi, N.V. Explaining foreign direct investment in Turkey's tourism industry. Transnat. Corp. 1996, 5, 99-110.

51. Ma, X.; Wang, Y.; Song, H.; Liu, H. Time-varying mechanisms between foreign direct investment and tourism development under the new normal in China. Tour. Econ. 2020, 26, 324-343. [CrossRef]

52. Selvanathan, S.; Selvanathan, E.A.; Viswanathan, B. Causality between foreign direct investment and tourism: Empirical evidence from India. Tour. Anal. 2012, 17, 91-98. [CrossRef]

53. Ravinthirakumaran, K.; Selvanathan, E.; Selvanathan, S.; Singh, T. Tourism and Foreign Direct Investment Inflows in Sri Lanka. South Asia Econ. J. 2019, 20, 248-273. [CrossRef]

54. Subbarao, P.S. A Study on Foreign Direct Investment (FDI) in Indian Tourism; IIMK: Kerala, India, 2008.

55. Van Parys, S.; James, S. The Effectiveness of Tax Incentives in Attracting FDI: Evidence from the Tourism Sector in the Caribbean; Universiteit Ghent: Ghent, Belgium, 2010.

56. Perić, J.; Radıć, M.N. Tourism productivity and tourism FDI in Croatia. Mediterr. J. Soc. Sci. 2015, 6, 425. [CrossRef]

57. Bezuidenhout, H.; Grater, S. The Dimensions of FDI in the Tourism Sector in Africa; North-West University: Potchefstroom, Africa, 2016.

58. Chen, X. The Influence of FDI on China's Tourism Industry; Auckland University of Technology: Auckland, New Zeland, 2010.

59. Sharma, A.; Johri, A.; Chauhan, A. FDI: An instrument of economic growth \& development in tourism industry. Int. J. Sci. Res. Publ. 2012, 2, 1-6.

60. Simatupang, P.; Chik, A.R. FDI in Tourism Sector and Economic Growth in Sumatra Utara. Winners 2014, 15, 150-158. [CrossRef]

61. Willem te Velde, D.; Nair, S. Foreign direct investment, services trade negotiations and development: The case of tourism in the Caribbean. Dev. Policy Rev. 2006, 24, 437-454. [CrossRef]

62. Daly, M.T.; Stimson, R.J.; Jenkins, O. Tourism and foreign investment in Australia: Trends, prospects and policy implications. Aust. Geogr. Stud. 1996, 34, 169-184. [CrossRef]

63. Barrowclough, D. Foreign investment in tourism and small island developing states. Tour. Econ. 2007, 13, 615-638. [CrossRef]

64. Peric, J.; Niksic Radic, M. Sustainable foreign direct investment in tourism sector of developing countries. Tour. South East Eur. 2011, 2011, 263-278.

65. Işik, C. Foreign direct investment in tourism: Panel data analysis of D7 countries. Athens J. Tour. 2015, 2, 93-103. [CrossRef]

66. Fortanier, F.; Van Wijk, J. Sustainable tourism industry development in sub-Saharan Africa: Consequences of foreign hotels for local employment. Int. Bus. Rev. 2010, 19, 191-205. [CrossRef]

67. Khoshnevis Yazdi, S.; Nateghian, N.; Sheikh Rezaie, N. The causality relationships between tourism development and foreign direct investment: An empirical study in EU countries. J. Pol. Res. Tour. Leisure Events 2017, 9, 247-263. [CrossRef]

68. Fayissa, B.; Nsiah, C.; Tadesse, B. Research note: Tourism and economic growth in Latin American countries-further empirical evidence. Tour. Econ. 2011, 17, 1365-1373. [CrossRef]

69. Phung-Tran, P.; Trang-Le, H. The Granger Causality Relationship between FDI, GDP and International Tourist Arrivals-Empirical evidence from 5 countries. In Proceedings of the Seventh Vietnam Economist Annual Meeting (VEAM 2014), Ho Chi Minh, Vietnam, 7-11 November 2014.

70. Das, R.K.; Chakraborty, J. An evaluative study on tourism in Bangladesh. Dev. Country Stud. 2012, 2, $17-27$.

71. Hassan, M.R.; Ullah, M.M.; Chowdhury, M.S.A. Impact of tourism in Bangladesh economy. World J. Soc. Sci. 2013, 3, $228-240$.

72. Aktar, M.A.; Sadekin, M.N.; Saha, S.K. Relationship between tourist arrival and foreign exchange earnings: The case for Bangladesh. Mediterr. J. Soc. Sci. 2014, 5, 162. [CrossRef]

73. Chowdhury, M.A.F.; Shahriar, F.M. The impact of tourism in a deficit economy: A conceptual model in Bangladesh perspective. Bus. Intell. J. 2012, 5, 163-168.

74. Bouchoucha, N.; Benammou, S. Does institutional quality matter foreign direct investment? Evidence from African countries. J. Knowl. Econ. 2018, 11, 1-15. [CrossRef] 
75. Masron, T.A.; Abdullah, H. Institutional quality as a determinant for FDI inflows: Evidence from ASEAN. World J. Manag. 2010, 2, $115-128$.

76. Masron, T.A.; Naseem, N. Institutional quality and foreign direct investment in ASEAN. Inst. Econ. 2017, 9, 5-30.

77. Shah, S.H.; Ahmad, M.H.; Ahmed, Q.M. The nexus between sectoral FDI and institutional quality: Empirical evidence from Pakistan. Appl. Econ. 2016, 48, 1591-1601. [CrossRef]

78. Hall, R.E.; Jones, C.I. Why do some countries produce so much more output per worker than others? Q. J. Econ. 1999, 114, 83-116. [CrossRef]

79. Globerman, S.; Shapiro, D.M. The impact of government policies on foreign direct investment: The Canadian experience. J. Int. Bus. Stud. 1999, 30, 513-532. [CrossRef]

80. Masron, T.A. Relative institutional quality and FDI inflows in ASEAN countries. J. Econ. Stud. 2017, 44, 115-137. [CrossRef]

81. Clarke, G.R. How institutional quality and economic factors impact technological deepening in developing countries. J. Int. Dev. 2001, 13, 1097-1118. [CrossRef]

82. Gastanaga, V.M.; Nugent, J.B.; Pashamova, B. Host country reforms and FDI inflows: How much difference do they make? World Dev. 1998, 26, 1299-1314. [CrossRef]

83. Mody, A.; Srinivasan, K. Japanese and US firms as foreign investors: Do they march to the same tune? Can. J. Econ. 1998, 31, 778-799. [CrossRef]

84. North, D.C. A transaction cost theory of politics. J. Theor. Pol. 1990, 2, 355-367. [CrossRef]

85. Nondo, C.; Kahsai, M.S.; Hailu, Y.G. Does institutional quality matter in foreign direct investment?: Evidence from Sub-Saharan African countries. Afr. J. Econ. Sustain. Dev. 2016, 5, 12-30. [CrossRef]

86. Azam, M.; Khan, H.; Hunjra, A.I.; Ahmad, H.M.; Chani, D.; Irfan, M. Institutional, macro economic policy factors and foreign direct investment: South Asian countries case. Afr. J. Bus. Manag. 2010, 5, 4306-4313.

87. Harms, P.; Ursprung, H.W. Do civil and political repression really boost foreign direct investments? Econ. Inq. 2002, 40, 651-663. [CrossRef]

88. Globerman, S.; Shapiro, D. Global foreign direct investment flows: The role of governance infrastructure. World Dev. 2002, 30, 1899-1919. [CrossRef]

89. Michael, P.; Nobay, A.R.; Peel, D.A. Transactions costs and nonlinear adjustment in real exchange rates: An empirical investigation. J. Pol. Econ. 1997, 105, 862-879. [CrossRef]

90. Haile, G.A.; Assefa, H. Determinants of Foreign Direct Investment in Ethiopia: A time-series analysis. In Proceedings of the 4th International Conference on the Ethiopian Economy, Addis Ababa, Ethiopia, 10-12 June 2006.

91. Ramirez, M.D. Economic and institutional determinants of foreign direct investment in Chile: A time-series analysis, 1960-2001. Contemp. Econ. Pol. 2006, 24, 459. [CrossRef]

92. Nasrin, S.; Baskaran, A.; Muchie, M. Major determinants and hindrances of FDI inflow in Bangladesh: Perceptions and experiences of foreign investors and policy makers. In Proceedings of the GLOBELICS—8th International Conference. Making Innovation Work for Society: Linking, Leveraging and Learning, Kuala Lumpur, Malaysia, 1-3 November 2010; pp. 1-3.

93. Esew, N.G.; Yaroson, E. Institutional quality and foreign direct investment (FDI) in Nigeria: A prognosis. IOSR J. Human. Soc. Sci. 2014, 19, 37-45. [CrossRef]

94. Fadhil, M.A.; Almsafir, M.K. The Role of FDI Inflows in Economic Growth in Malaysia (Time Series: 1975-2010). Proc. Econ. Financ. 2015, 23, 1558-1566. [CrossRef]

95. Nguyen, T.V.H.; Cao, T.H.V. The Impact of Institutional Quality on Foreign Direct Investment (FDI) Inflows to Vietnam. EADN Working Pap. 2015, 86, 28.

96. Hussain, M.E.; Haque, M. Foreign direct investment, trade, and economic growth: An empirical analysis of Bangladesh. Economies 2016, 4, 7. [CrossRef]

97. Mahmood, H. An investigation of macroeconomic determinants of FDI inflows in Bangladesh. Acad. Account. Financ. Stud. J. 2018, 22, 1-7.

98. Chowdhury, A.; Mavrotas, G. FDI and growth: What causes what? World Econ. 2006, 29, 9-19. [CrossRef]

99. Busse, M.; Hefeker, C. Political risk, institutions and foreign direct investment. Eur. J. Pol. Econ. 2007, 23, 397-415. [CrossRef]

100. Hyun, H.J. Quality of institutions and foreign direct investment in developing countries: Causality tests for cross-country panels. J. Bus. Econ. Manag. 2006, 7, 103-110. [CrossRef]

101. Mina, W. The location determinants of FDI in the GCC countries. J. Multinat. Financ. Manag. 2007, 17, 336-348. [CrossRef]

102. Kostevc, Č.; Redek, T.; Sušjan, A. Foreign direct investment and institutional environment in transition economies. Transit. Stud. Rev. 2007, 14, 40-54. [CrossRef]

103. Bénassy-Quéré, A.; Coupet, M.; Mayer, T. Institutional determinants of foreign direct investment. World Econ. 2007, 30, 764-782. [CrossRef]

104. Daude, C.; Stein, E. The quality of institutions and foreign direct investment. Econ. Pol. 2007, 19, 317-344. [CrossRef]

105. Rose-Ackerman, S.; Tobin, J. Foreign direct investment and the business environment in developing countries: The impact of bilateral investment treaties. Yale Law Econ. Res. Pap. 2005, 293, 52. [CrossRef]

106. Hattari, R.; Rajan, R.S. Understanding bilateral FDI flows in developing Asia. Asian Pac. Econ. Lit. 2009, 23, 73-93. [CrossRef]

107. Ali, F.A.; Fiess, N.; MacDonald, R. Do institutions matter for foreign direct investment? Open Econ. Rev. 2010, 21, 201-219. [CrossRef] 
108. Shahadan, F.; Sarmidi, T.; Faizi, F.J. Relationships between doing business indexes and FDI net inflows: Empirical evidence from six Asian countries (Afghanistan, Bangladesh, India, Iran, Pakistan and Sri Lanka). Persidang. Kebangs. Ekon. Malays. 2014, 9, 609-625.

109. Fukumi, A.; Nishijima, S. Institutional quality and foreign direct investment in Latin America and the Caribbean. Appl. Econ. 2010, 42, 1857-1864. [CrossRef]

110. Bissoon, O. Can better institutions attract more foreign direct investment (FDI)? Evidence from developing countries. In Proceedings of the International Conference on Applied Economics, Perugia, Italy, 7 October 2011; pp. 59-70.

111. Tun, Y.-L.; Azman-Saini, W.; Law, S.-H. International evidence on the link between foreign direct investment and institutional quality. Eng. Econ. 2012, 23, 379-386. [CrossRef]

112. Asiedu, E. Foreign Direct Investment, Natural Resources and Institutions; International Growth Centre: London, UK, 2013.

113. Dang, D.A. How foreign direct investment promote institutional quality: Evidence from Vietnam. J. Comp. Econ. 2013, 41, 1054-1072. [CrossRef]

114. Fiodendji, D. Do Institutions Quality Affect FDI Inflows in Sub Saharan African Countries? MPRA: 2013. Available online: https: / / mpra.ub.uni-muenchen.de/57414/ (accessed on 3 September 2021).

115. Cristina, J.; Levieuge, G. Growth Effect of FDI in Developing Economies: The Role of Institutional Quality; Orleans Economics Laboratory/Laboratoire d'Economie d'Orleans LEO: Orleans, LA, USA, 2013.

116. Masron, T.A.; Nor, E. FDI in ASEAN-8: Does institutional quality matter? Appl. Econ. Lett. 2013, 20, 186-189. [CrossRef]

117. Herrera-Echeverri, H.; Haar, J.; Estévez-Bretón, J.B. Foreign direct investment, institutional quality, economic freedom and entrepreneurship in emerging markets. J. Bus. Res. 2014, 67, 1921-1932. [CrossRef]

118. Jude, C.; Levieuge, G. Growth Effect of FDI in Developing Economies: The Role of Institutional Quality; SSRN: Rochester, NY, USA, 2015.

119. Asamoah, M.E.; Adjasi, C.K.; Alhassan, A.L. Macroeconomic uncertainty, foreign direct investment and institutional quality: Evidence from Sub-Saharan Africa. Econ. Syst. 2016, 40, 612-621. [CrossRef]

120. Kurul, Z.; Yalta, A.Y. Relationship between institutional factors and FDI flows in developing countries: New evidence from dynamic panel estimation. Economies 2017, 5, 17. [CrossRef]

121. Kurul, Z. Nonlinear relationship between institutional factors and FDI flows: Dynamic panel threshold analysis. Int. Rev. Econ. Financ. 2017, 48, 148-160. [CrossRef]

122. Jude, C.; Levieuge, G. Growth effect of foreign direct investment in developing economies: The role of institutional quality. World Econ. 2017, 40, 715-742. [CrossRef]

123. Bokpin, G.A.; Mensah, L.; Asamoah, M.E. Legal source, institutional quality and FDI flows in Africa. Int. J. Law Manag. 2017, 59, 687-698. [CrossRef]

124. Aziz, O.G. Institutional quality and FDI inflows in Arab economies. Financ. Res. Lett. 2018, 25, 111-123. [CrossRef]

125. Van Bon, N. Effects of Institutional Quality on FDI in Provinces of Vietnam: Empirical Evidence Based on Differenced Panel GMM. J. Econ. Dev. 2019, 22, 26-45. [CrossRef]

126. Uysal, M.; Crompton, J.L. Determinants of demand for international tourist flows to Turkey. Tour. Manag. 1984, 5, 288-297. [CrossRef]

127. Akal, M. Forecasting Turkey's tourism revenues by ARMAX model. Tour. Manag. 2004, 25, 565-580. [CrossRef]

128. Shoaib, M.; Siddiqui, I.; Amir, Y.M.; Rehman, S.U. Evaluation of wind power potential in Baburband (Pakistan) using Weibull distribution function. Renew. Sustain. Energy Rev. 2017, 70, 1343-1351. [CrossRef]

129. Aizenman, J.; Spiegel, M.M. Institutional efficiency, monitoring costs and the investment share of FDI. Rev. Intern. Econ. 2006, 14, 683-697. [CrossRef]

130. Levchenko, A.A. Institutional Quality and International Trade. Rev. Econ. Stud. 2007, 74, 791-819. [CrossRef]

131. Habib, M.; Zurawicki, L. Corruption and foreign direct investment. J. Int. Bus. Stud. 2002, 33, 291-307. [CrossRef]

132. Wijeweera, A.; Dollery, B. Host country corruption level and Foreign Direct Investments inflows. Int. J. Trade Glob. Markets 2009, 2, 168-178. [CrossRef]

133. Kaufmann, D.; Kraay, A.; Mastruzzi, M. Governance indicators for 2000-2008, the worldwide governance indicators (WGI) project. World Bank Pol. Res. 2010, 7. Available online: http://info.worldbank.org/governance/wgi/pdf/wgi.pdf (accessed on 3 September 2021).

134. Le, T.-H.; Kim, J.; Lee, M. Institutional quality, trade openness, and financial sector development in Asia: An empirical investigation. Emerg. Markets Financ. Trade 2016, 52, 1047-1059. [CrossRef]

135. Asamoah, M.E.; Alagidede, I.P. Foreign direct investment, real sector growth and financial development. Int. J. Finan. Econ. 2021. Available online: https:/ / onlinelibrary.wiley.com/doi/10.1002/ijfe.2440 (accessed on 3 September 2021). [CrossRef]

136. Carkovic, M.V.; Levine, R. Does Foreign Direct Investment Accelerate Economic Growth? Center for Global Development: Washington, DC, USA, 2002.

137. Hayat, A. Foreign direct investments, institutional quality, and economic growth. J. Int. Trade Econ. Dev. 2019, $28,561-579$. [CrossRef]

138. Breusch, T.S.; Pagan, A.R. The Lagrange multiplier test and its applications to model specification in econometrics. Rev. Econ. Stud. 1980, 47, 239-253. [CrossRef]

139. Pesaran, M.H. General Diagnostic Tests for Cross Section Dependence in Panels; CESifo GmbH: München, Germany, 2004. 
140. Pesaran, M.H. Estimation and inference in large heterogeneous panels with a multifactor error structure. Econometrica 2006, 74, 967-1012. [CrossRef]

141. Pesaran, M.H.; Ullah, A.; Yamagata, T. A bias-adjusted LM test of error cross-section independence. Econom. J. 2008, 11, 105-127. [CrossRef]

142. Pesaran, M.H. A simple panel unit root test in the presence of cross-section dependence. J. Appl. Econom. 2007, 22, 265-312 [CrossRef]

143. Jia, Z.; Mehta, A.M.; Qamruzzaman, M.; Ali, M. Economic Policy uncertainty and financial innovation: Is there any affiliation? Front. Psychol. 2021, 12, 1781. [CrossRef]

144. Zhang, Y.; Qamruzzaman, M.; Karim, S.; Jahan, I. Nexus between economic policy uncertainty and renewable energy consumption in BRIC Nations: The mediating role of foreign direct investment and financial development. Energies 2021, 14, 4687. [CrossRef]

145. Qamruzzaman, M.; Wei, J. Do financial inclusion, stock market development attract foreign capital flows in developing economy: A panel data investigation. Q. Financ. Econ. 2019, 3, 88-108. [CrossRef]

146. Pedroni, P. Panel cointegration: Asymptotic and finite sample properties of pooled time series tests with an application to the PPP hypothesis. Econom. Theory 2004, 20, 597-625. [CrossRef]

147. Pedroni, P. Purchasing power parity tests in cointegrated panels. Rev. Econ. Stat. 2001, 83, 727-731. [CrossRef]

148. Kao, C. Spurious regression and residual-based tests for cointegration in panel data. J. Econom. 1999, 90, 1-44. [CrossRef]

149. Westerlund, J. Testing for error correction in panel data. Oxf. Bull. Econ. Stat. 2007, 69, 709-748. [CrossRef]

150. Pesaran, M.H.; Shin, Y.; Smith, R.P. Pooled mean group estimation of dynamic heterogeneous panels. J. Am. Stat. Assoc. 1999, 94, 621-634. [CrossRef]

151. Chudik, A.; Pesaran, M.H. Common correlated effects estimation of heterogeneous dynamic panel data models with weakly exogenous regressors. J. Econom. 2015, 188, 393-420. [CrossRef]

152. Zapata, H.O.; Rambaldi, A.N. Monte Carlo evidence on cointegration and causation. Oxf. Bull. Econ. Stat. 1997, 59, 285-298. [CrossRef]

153. Levin, A.; Lin, C.-F.; Chu, C.-S.J. Unit root tests in panel data: Asymptotic and finite-sample properties. J. Econom. 2002, 108, 1-24. [CrossRef]

154. Im, K.S.; Pesaran, M.H.; Shin, Y. Testing for unit roots in heterogeneous panels. J. Econom. 2003, 115, 53-74. [CrossRef]

155. Breitung, J. The local power of some unit root tests for panel data. In Nonstationary Panels, Panel Cointegration, and Dynamic Panels; Emerald Group Publishing Limited: Bingley, UK, 2001; pp. 161-177.

156. Maddala, G.S.; Wu, S. A comparative study of unit root tests with panel data and a new simple test. Oxf. Bull. Econ. Stat. 1999, 61, 631-652. [CrossRef]

157. Hadri, K. Testing for stationarity in heterogeneous panel data. Econom. J. 2000, 3, 148-161. [CrossRef]

158. Gengenbach, C.; Palm, F.C.; Urbain, J.-P. Panel unit root tests in the presence of cross-sectional dependencies: Comparison and implications for modelling. Econom. Rev. 2009, 29, 111-145. [CrossRef]

159. Dogan, E.; Aslan, A. Exploring the relationship among CO2 emissions, real GDP, energy consumption and tourism in the EU and candidate countries: Evidence from panel models robust to heterogeneity and cross-sectional dependence. Renew. Sustain. Energy Rev. 2017, 77, 239-245. [CrossRef]

160. La Porta, R.; Lopez-de-Silanes, F.; Shleifer, A.; Vishny, R. The quality of government. J. Law Econ. Org. 1999, 15, $222-279$. [CrossRef]

161. Delgado, M.S.; McCloud, N. Foreign direct investment and the domestic capital stock: The good-bad role of higher institutional quality. Emp. Econ. 2017, 53, 1587-1637. [CrossRef]

162. Kim, S.; Choi, B. The Impact of the Technological Capability of a Host Country on Inward FDI in OECD Countries: The Moderating Roles of Institutional Quality. Sustainability 2020, 12, 9711. [CrossRef]

163. Qamruzzaman, M.; Jianguo, W. Investigation of the asymmetric relationship between financial innovation, banking sector development, and economic growth. Q. Financ. Econ. 2018, 2, 952-980. [CrossRef]

164. Jushi, E.; Hysa, E.; Cela, A.; Panait, M.; Voica, M.C. Financing Growth through Remittances and Foreign Direct Investment: Evidences from Balkan Countries. J. Risk Financ. Manag. 2021, 14, 117. [CrossRef]

165. Alfaro, L.; Chanda, A.; Kalemli-Ozcan, S.; Sayek, S. Does foreign direct investment promote growth? Exploring the role of financial markets on linkages. J. Develop. Econ. 2010, 91, 242-256. [CrossRef] 